Review

Open Ac cess

\title{
Pharmacological and Phytochemical Appraisal of Selected Medicinal Plants from J ordan with Claimed Antidiabetic Activities
}

\author{
Fatma U. AFIFI *, Violet KASABRI
}

Faculty of Pharmacy, The University of Jordan, Queen Rania Al-Abdullah Street, 11942 Amman, Jordan.

* Corresponding author. E-mail: fatueafi@ju.edu.jo (F. U. Afifi)

Sci Pharm. 2013; 81: 889-932

doi:10.3797/scipharm.1212-20

Published: $\quad$ October $15^{\text {th }} 2013$

Accepted: October $15^{\text {th }} 2013$

Received: $\quad$ December $20^{\text {th }} 2012$

This article is available from: http://dx.doi.org/10.3797/scipharm.1212-20

(c) Afifi and Kasabri; licensee Österreichische Apotheker-Verlagsgesellschaft m. b. H., Vienna, Austria.

This is an Open Access article distributed under the terms of the Creative Commons Attribution License (http://creativecommons.org/licenses/by/3.0/), which permits unrestricted use, distribution, and reproduction in any medium, provided the original work is properly cited.

\begin{abstract}
Plant species have long been regarded as possessing the principal ingredients used in widely disseminated ethnomedical practices. Different surveys showed that medicinal plant species used by the inhabitants of Jordan for the traditional treatment of diabetes are inadequately screened for their therapeutic/preventive potential and phytochemical findings. In this review, traditional herbal medicine pursued indigenously with its methods of preparation and its active constituents are listed. Studies of random screening for selective antidiabetic bioactivity and plausible mechanisms of action of local species, domesticated greens, or wild plants are briefly discussed. Recommended future directives incurring the design and conduct of comprehensive trials are pointed out to validate the usefulness of these active plants or bioactive secondary metabolites either alone or in combination with existing conventional therapies.
\end{abstract}

\section{Keywords}

Traditional medicine $\bullet$ Medicinal plants $•$ Diabetes $\bullet$ Jordan $\bullet$ Ethnomedicine

\section{Introduction}

Diabetes mellitus (DM) is highly recognised as the most common metabolic and endocrine disorder worldwide. It is linked to disturbances in carbohydrate, fat, and protein metabolism [1]. It is especially important because the global prevalence of diabetes is projected to escalate relentlessly. At least 250 million individuals worldwide suffer from diabetes and this number will double by 2030 . Increases in complications will undeniably 
follow increasing diabetes incidence rates [2]. More than $80 \%$ of diabetes deaths take place in low- and middle-income countries [3].

The regional prevalence of diabetes in MENA (Middle Eastern and North Africa) countries is $7.7 \%$. Locally, endocrine, nutritional, and metabolic diseases represent $7.9 \%$ of deaths in Jordan [3-5]. With a prevalence rate at 10.1\%, Jordan has the ninth highest incidence of diabetes among neighbouring countries. Several national surveys designated that the prevalence of type 2 diabetes and impaired fasting glycemia is unprecedentedly high, amounting to an epidemiological transition in Jordan [6-8].

Undoubtedly, Jordan's habitat is exceptional. It is at the intersection of arid desert, dense forest, and tropical geography, thus bestowing the country with a rich variety of plants and microorganisms that can be resourcefully studied (Fig. 1) [9]. The heterogeneous ecological conditions have favoured the proliferation of more than 2,500 wild plant species from 700 genera; of these, there are approximately 100 endemic species, 250 rare species, and 125 very rare species [9-11]. Unfortunately, this substantial biodiversity is principally understudied, or even worse, left unexplored [9-12].

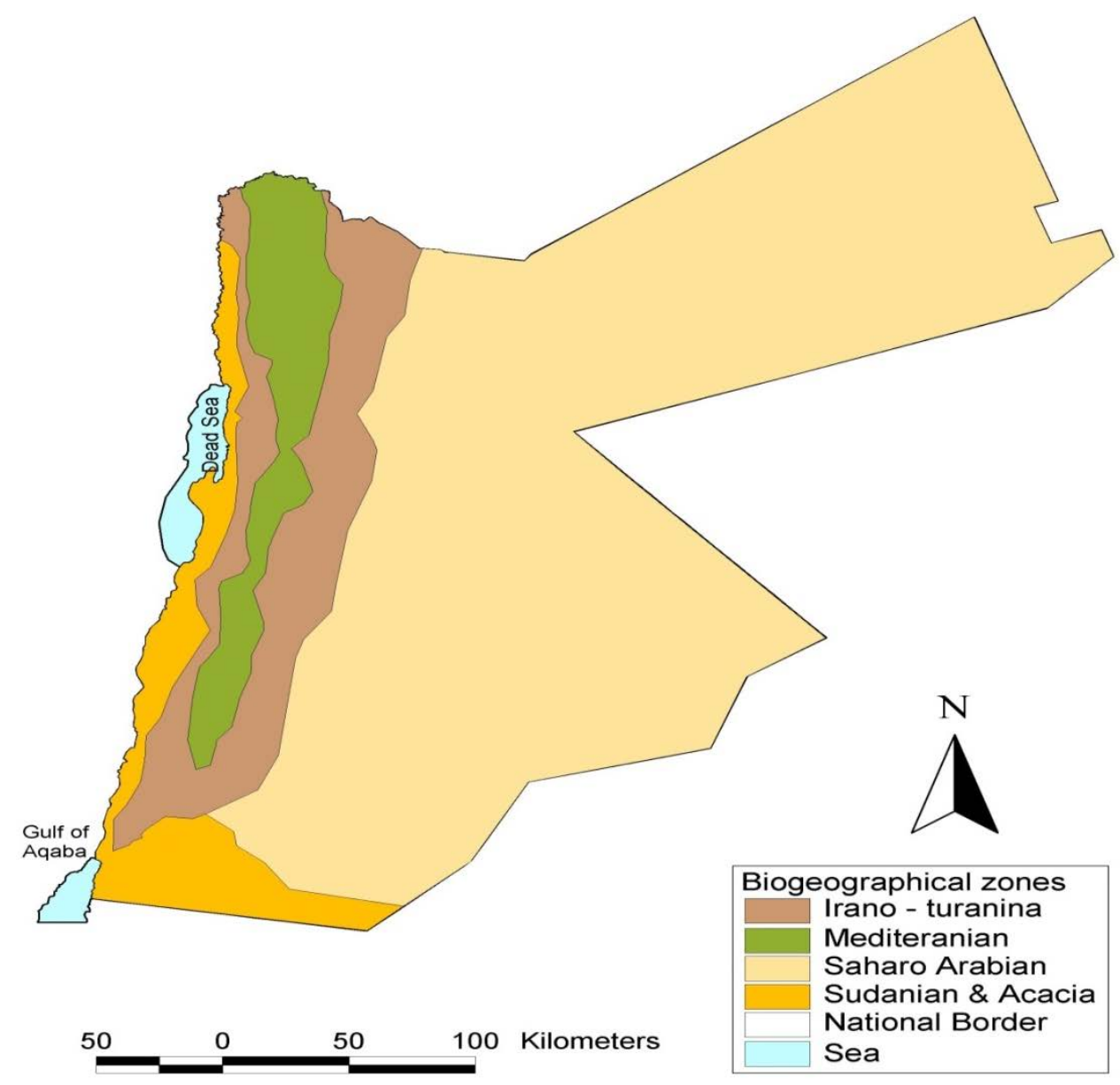

Fig. 1. Biogeographic zones of Jordan 
Apparently, there is a repository of ethnobotanical studies in the Mediterranean basin, providing a new and key tool for a quest after invaluable phytopharmaceuticals or the development of functional foods or nutraceuticals [13-20]. Traditional medicine practices, being part of the Jordanian culture, are considered responsible for an impartial role in primary health care despite modern medicine accessibility [21] where vegetables, culinary herbs, and medicinal plants are among the main choices in the management of diabetes $[13,21-30]$. Essentially important, traditional medicine has not only survived, but thrived in the transcultural environment and intermixture of many ethnic traditions and beliefs despite the 'aging' or 'vanishing' of folk phytotherapy in the sense that the wealth of knowledge of medicinal plants resides mostly in elderly rural people with modest tuition [31]. Also, it is officially neither integrated in the health care system nor recognized in the national policies of the country. Furthermore, as the use of medicinal plant remedies constitutes the common legacy of Jordanians, reliability fractions on herbal medicine vary from rural and desert areas to heavily populated urban ones [21-24]. In the last decades, more plants have been added to the list of endangered species. This results in the urgent inevitability for local communities to implement nationwide conservation and sustainability programs [32].

The objective of this review is to emphasize the ethnopharmacological practices related to 20 selected ethnobotanicals with claimed antidiabetic properties in light of their comprehensive scientific evaluation and bioactive plant secondary metabolites. Considering the hugely diverse plant species in diabetes traditional medicine, the present manuscript can be complementary to our previous report of 30 indigenous plants [33]. In fact, all our attempts in this direction serve to bring together the Jordanian inventory of diabetes ethnomedicine. Still, further studies might also be integrated into this line of work.

\section{Results and Discussion}

Based on centuries of beliefs and observations, plants are primarily used in preparatory forms of infusions or decoctions in ethnomedicinal practices. Worldwide, more than 1,200 species of plants have been reported to be used empirically for their claimed antidiabetic activity [34] while in the Jordanian traditional medicine, almost 70 plant species are used by diabetic patients. Although indigenously grown plants are consumed in the countryside, in the vast cities, including the capital Amman, however, the herbalists' shops display a wide variety of imported plant species, like Zingiber officinalis, Terminalia chebula, or Emblica officinalis, alongside the likely obtainable native ones [11, 23, 35, 36].

On the other hand, reports on the concomitant use of plants in orthodox therapy are evidently understated. In this aspect, interviews with diabetes patients in specialized health centres in Jordan further signified a more diversified list of selected plants $[21,26]$. The reported plants were: Camellia sinensis, Pimpinella anisum, Zingiber officinale, Matricaria recutita, Salvia fruticosa, Trigonella foenum-graecum, Nigella sativa, Lupinus albus, Teucrium polium, Allium sativum, Cinnamomum zeylanicum, and Olea europea. It is tempting to speculate that the high frequency of use is related to the high efficacy and safety of the plant material, such as green tea, aniseed, or chamomile, although there are no clinical studies to indicate monitoring of glucose and haemoglobin A1c levels in diabetic patients using these plants [31]. Also, there is no information available on the protection from target organ damage by the long-term use of plant products. Interestingly, white lupin (Lupinus albus), fenugreek (Trigonella foenum-graecum), garlic (Allium sativum), olive 
leaves (Olea europea), ginger (Zingiber officinale), felty germander (Teucrium polium), or black fennel (Nigella sativa) were not the top/main preference herbs of choice by the Jordanian diabetic patients $[21,26]$, despite being scientifically appraised for their antidiabetic activities and frequent use in communities abroad. This has lent further weight to our major interests and concerns stemming from the unjustified claims and selection pressure of certain herbal ethnomedicines in the treatment of diabetes.

Obviously, the significant efficacy of hypoglycaemic herbs, obtainable, via functioning as pancreatic insulin secretagogues and extrapancreatic insulin mimetics, enhancing glucose uptake by adipose and muscle tissues, or via inhibiting hepatic gluconeogenesis and intestinal carbohydrate digestibility and absorption, is comparable to conventional diabetes pharmacotherapeutics [37-39]. Literature surveys of botanicals with traditional uses, critically withstanding pharmacological appraisal, indicated that local target-based and mechanistic reports on diabetes interventional phytotherapies are primarily limited and inadequate. Gharaibeh et al. [40] investigated the hypoglycaemic effects of the aqueous extract of Teucrium polium in normal and streptozocin (STZ)-diabetic rats. Additionally, the hypoglycaemic effects of Ballota nigra [41] and Artemisia sieberi [42] were evidenced in alloxan-diabetic rats. Also, the antioxidative properties of an extensive list of Jordanian plants with diabetes ethnotherapeutic claims were closely discussed [43]. In other studies from Jordan, the pancreatic effects of the antidiabetic plants Eriobotrya japonica [44] and Ferula asafoetida were reported [45]. Further comprehensive in vitro and in vivo examinations of indigenous herbs valued as antidiabetic phytomedicines, including Achillea santolina, Eryngium creticum, Geranium graveolens, Paronychia argentea, Pistacia atlantica, Rheum ribes, Sarcopoterium spinosum, Teucrium polium, and Varthemia iphionoides, have been recognised with elaboration [46-49]. These research findings could collectively resonate with the prevention/modulation of postprandial hyperglycaemia, budding from the natural therapeutic inhibitors of $\alpha$-amylase and $\alpha$ glucosidase, with ethnopharmacological claims in the local communities.

Table 1, demonstrating the antidiabetic and/or other pharmacological activities of the compiled 20 plants, provides an updated overview of their reported phytoconstituents as well. In the present review, flavonoids are among the major classes of secondary metabolites detected in most of the tabulated plants. The antidiabetic activity is welldocumented for numerous flavonoids [50]. Achillea santolina and A. fragrantissima are widely distributed in Jordan and used for their claimed antidiabetic activities. In STZ diabetic rats, hypoglycaemic activity was only evaluated for the former species though both species are rich in flavonoids among other similar volatile oil constituents. Hence, an antidiabetic activity can be likely assumed and verified for flavonoid-rich $A$. fragrantissima [51]. Also, the promoted antidiabetic activity of Anthemis pseudocotula might be due largely to its flavonoid content. On equal footing, similar postulations can be deduced for plant species with reported antioxidative capacities. Basically, natural antioxidants are well-linked with antidiabetic therapeutic/preventive pharmacology [34, 43, 52-55]. Consequently, despite the lack of scientific scrutiny, it can be speculated that the antioxidative propensities of Alhagi marourum, Alchemilla vulgaris, Cucurbita maxima, Juniperus phoenicea, Quercus coccifera, and Ambrosia maritima can in principle justify their reported phytotherapeutic claims and ethnomedicinal uses. 
Tab. 1. Antidiabetic plants indigenous to Jordan used for the treatment of diabetes in folk medicine in Jordan.

\begin{tabular}{|c|c|c|c|}
\hline \multirow{2}{*}{ No- } & Species & \multirow{2}{*}{$\begin{array}{l}\text { Reported antidiabetic } \\
\text { efficacy and/or } \\
\text { mechanism of action }\end{array}$} & \multirow{2}{*}{$\begin{array}{c}\text { Other reported } \\
\text { pharmacological effects }\end{array}$} \\
\hline & Reported phytoconstituents & & \\
\hline 1 & $\begin{array}{l}\text { Flavonoids [67-69]. Essential oil } \\
\text { (santolina alcohol, artemisia } \\
\text { alcohol, artemisia ketone, } \\
\text { cis-thujone and trans-thujone, } \\
\text { 1,8-cineole, fragranol, fragranyl } \\
\text { acetate and terpin-4-ol) [70]. }\end{array}$ & \multicolumn{2}{|c|}{$\begin{array}{c}\text { Antioxidative effects [43]. Lacked } \\
\text { any antirheumatic or anti- } \\
\text { inflammatory effects in } \\
\text { carrageenan-induced acute } \\
\text { inflammation in rats [71], but } \\
\text { exerted antimicrobial and antiviral } \\
\text { activities [70, 72-75]. Modulatory } \\
\text { effects on rat ileum muscle } \\
\text { contraction [74]. Beneficial in } \\
\text { preventing/treating neuro- } \\
\text { degenerative diseases [76]. } \\
\text { Aqueous extract exhibited strong } \\
\text { cytotoxicity and larvicidal } \\
\text { activities [77, 78]. }\end{array}$} \\
\hline 2 & $\begin{array}{c}\text { Asteraceae } \\
\text { Achillea santolina L. } \\
\text { (Infusion of leaves, flowering } \\
\text { branches [24]) } \\
\text { Flavonoids such as luteolin, } \\
\text { quercetin, cosmosiin, hyperoside } \\
\text { and cynaroside [79-81], } \\
\text { terpenoids [82]. Essential oil } \\
\text { (1,8-cineole, fragranol, fragranyl } \\
\text { acetate and terpin-4-ol) [70]. }\end{array}$ & $\begin{array}{l}\text { Hypoglycemic activity in } \\
\text { STZ rats due to } \\
\text { antioxidative potential [51, } \\
\text { 83-84]. Lack of significant } \\
\text { inhibition of } \alpha \text {-amylase and } \\
\text { a-glucosidase in vitro } \\
\text { despite acute } \\
\text { antihyperglycemic trend in } \\
\text { starch fed rats [48]. }\end{array}$ & $\begin{array}{c}\text { Enhancement of } \\
\text { antimicrobial efficacy } \\
\text { against antibiotic resistant } \\
\text { E. coli and other } \\
\text { microorganisms [85, 86]. } \\
\text { Potent anti-inflammatory } \\
\text { and immunomodulatory } \\
\text { activities [87]. }\end{array}$ \\
\hline 3 & $\begin{array}{l}\text { Sesquiterpenes and } \\
\text { sesquiterpene lactones [88-90]. } \\
\text { Thiophene A and thiophene A diol } \\
\text { as major polyacetylenes [91]. }\end{array}$ & \multicolumn{2}{|c|}{$\begin{array}{c}\text { Cytotoxicity [88]. Effective } \\
\text { molluscicidal activity [92-96] but } \\
\text { little or no effect on the larvae of } \\
\text { Anopheles stephensi and Aedes } \\
\text { aegypti [97, 98] as well as } \\
\text { hepatoprotective and antioxidant } \\
\text { properties [99]. Antifungal activity } \\
\text { of its sesquiterpenes [89]. }\end{array}$} \\
\hline
\end{tabular}

Asteraceae

Anthemis pseudocotula Boiss

(Infusion of flowering heads, leaves [24])

$4 \quad$ Flavonoids (apigenin, apigenin-7-

glucoside) and coumarins (scopoletin and

NONE NONE

herniarin) [100]. Essential oil [101],

sesquiterpenes and sesquiterpene

lactones [102, 103]. 
Tab. 1. (Cont.)

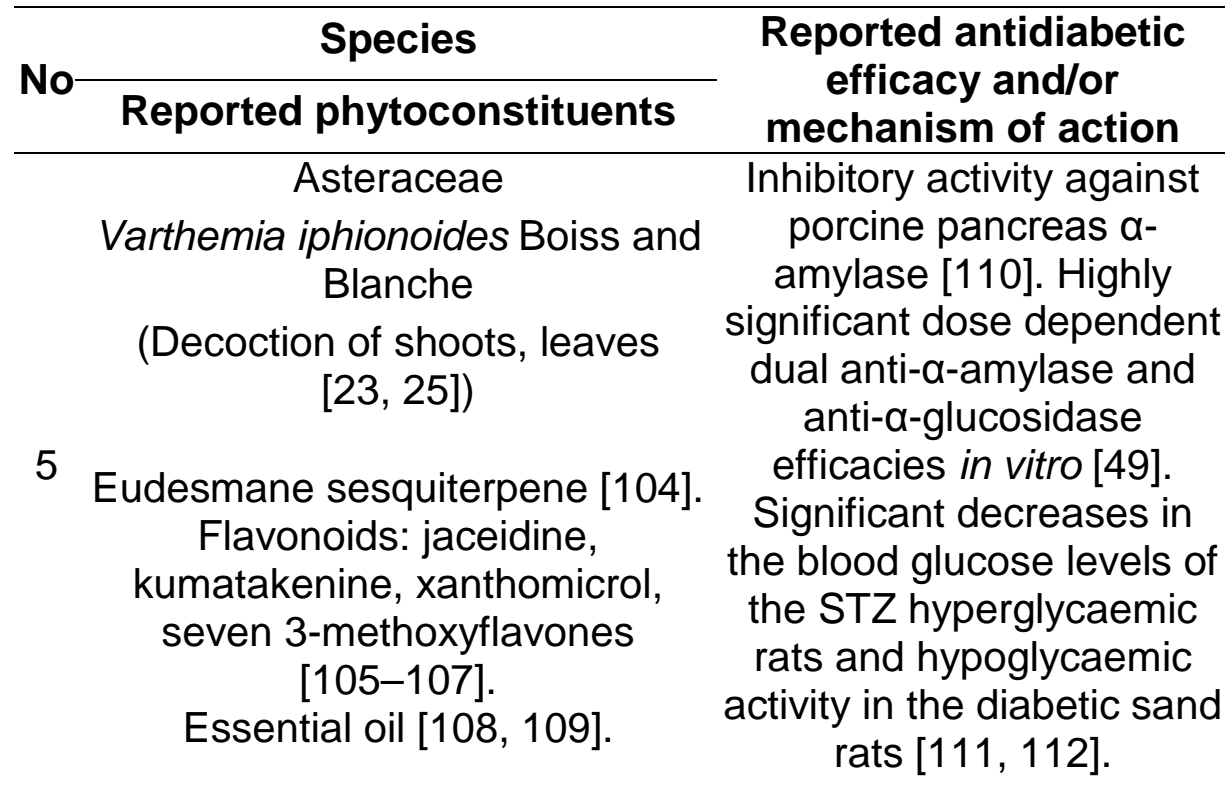

\section{Other reported pharmacological effects}

Antiplatelets benefits [113] as well as antioxidative effects [43, 105, 110, 114]. Cytotoxic effect on human leukemia (HL-60) and antitumor properties [105, 115]. Pronounced antibacterial and antifungal propensities

$[86,105,106,116]$.

\section{Capparaceae \\ Cleoma droserifolia \\ (Forskal) Delil}

(Decoction of leaves [24])

6

Terpenes, flavonoids (quercetin, kaempferol, and isorhamnetin) and phenolic acids [117122].
Hypoglycaemic efficacy via potentiation of peripheral and hepatic insulin sensitivity, thus decreasing hepatic glucose output. Also decreasing intestinal glucose absorption, which was evident by blunting plasma glucose levels throughout the oral glucose challenge in tetracycline-induced fatty liver rats [123]. Insulin induction activity [124]; restored the blood glucose level, plasma

malondialdehyde, and urine sugar to near the physiological values [121].

In alloxan-induced diabetic mice reduced oxidative stress in addition to antihyperglcemic activity [125].
Suppressive effect on NO production in activated macrophages in vitro [117]. Hepato-protective effect

[119]. Hypocholesterolemic and protective antiatherogenic benefits in tetracycline induced fatty liver in rats [123].

Hypolipidemic, antioxidative and anti-Schistosomiasis mansoni properties [124126]. Hepatotoxicity in coculture systems [127].

Significant cytotoxic activity against breast (MCF7) and colon (HCT116) cancer cell lines [122].

\section{Cucurbitaceae}

Cucurbita maxima Duchesne

(Dry seeds [23])

Spinasterol [128]. Carotenoids (violaxanthin, beta-carotene) and lutein [129]. Tocopherols, fatty acids (oleic, linoleic, and palmitic acids), beta sitosterol and phenolic acids [130-133]. Water soluble polysaccharide fraction [134]. Volatile compounds, such as lipid aldehydes, ethyl acetate, 2,3-butanedione, and dimethylsulfide [135].
Wistar rats treated for 70 days with pumpkin seed flour exhibited significant decrease in glucose and triacylglycerides [136].
Antigenotoxic principle [128] and antioxidative benefits [134]. Trypsin inhibition [137, 138]. Larvicidal, ovicidal and repellent properties against mosquito bites [139]. 
Tab. 1. (Cont.)

\begin{tabular}{|c|c|c|c|}
\hline No- & Reported phytoconstituents & $\begin{array}{l}\text { Reported antidiabetic } \\
\text { efficacy and/or } \\
\text { mechanism of action }\end{array}$ & $\begin{array}{c}\text { Other reported } \\
\text { pharmacological effects }\end{array}$ \\
\hline 8 & 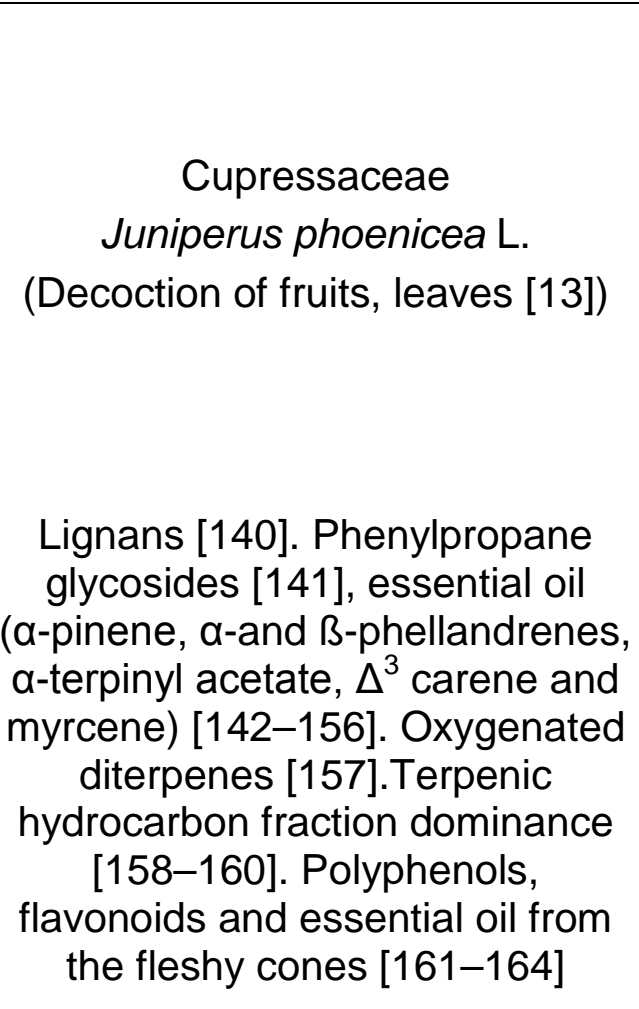 & $\begin{array}{rr} & \text { Antica } \\
\text { cyto } \\
& 156,1 \\
\text { and I } \\
\text { aflato } \\
\text { foods [1 } \\
160, \\
\text { agair } \\
\text { Anti } \\
\text { antifo } \\
\text { with tic } \\
\text { Antiox } \\
164,16 \\
\text { effect it } \\
\text { functic } \\
\text { may thı } \\
\text { in trea } \\
\text { nephrc } \\
\\
\\
\text { Antic }\end{array}$ & $\begin{array}{l}\text { ncer constituents [140] and } \\
\text { toxicity against } 5 \text { cell lines } \\
57] \text {. Antimicrobial properties } \\
\text { helpful in the prevention of } \\
\text { xin contamination for many } \\
\text { L44, 150, 153, 154, 156, 159, } \\
\text { 163-166]. Potent activity } \\
\text { ist Candida albicans [143]. } \\
\text { parasitic, nematicidal and } \\
\text { lling constituents [155, 167] } \\
\text { k repellent properties [168]. } \\
\text { idative [152, 159, 160, 162, } \\
6] \text { propensities. Remarkable } \\
\text { n enhancing liver and kidney } \\
\text { ons in CCl }{ }_{4} \text { treated rats, and } \\
\text { us be of therapeutic potential } \\
\text { tment of hepatotoxicity and } \\
\text { otoxicity [169, 170]. Wound- } \\
\text { healing effect [171]. } \\
\text { holinesterase activity [148, } \\
166] \text {. }\end{array}$ \\
\hline
\end{tabular}

Fagaceae

Quercus coccifera L.

(Decoction of galls [13])

9 Polyphenols and tannins

(pedunculagin, castalagin,

phillyraeoidin $A$, and

acutissimin B) $[164,172,173]$.

Sesquiterpenes [174].
NONE

Antioxidant and antibacterial properties [164]. Anti-lipoperoxidant properties-related gastroprotective and antiulcerogenic effects [173, 175]. Anthelmintic activity against parasitic nematodes [176].

\section{Geraniaceae}

Geranium graveolens L.

(Decoction of leaves [13, 24])

10
Dual inhibition of $\alpha$-amylase and $\alpha$ glucosidase in vitro, confirmed by highly significant and potent acute antihyperglycemic chemotherapy and/or radiotherapy to trends in starchfed rats [49].
Fumigant antitermitic activity [179].

Antioxidant activity [182]. Repellent effect against host-seeking nymphs of Ixodes ricinus [183] with antimicrobial qualities [180, 184, 185]. Mosquito repellent property [186]. Improves the immune cell count of cancer patients receiving prevent leucopenia and immune impairment that usually occurs during cancer therapy [187]. 
Tab. 1. (Cont.)

\begin{tabular}{lcc}
\hline No & Species & $\begin{array}{c}\text { Reported antidiabetic } \\
\text { efficacy and/or } \\
\text { mechanism of action }\end{array}$ \\
\hline
\end{tabular}

Labiatae

Ajuga iva L. (Schreber)

(Decoction of herb [24])

11

\author{
14,15-dihydroajugapitin [188] \\ Ecdysones [189] and \\ phytoecdysteroids [190, 191]. \\ Iridoids, such as \\ 8-O-acetylharpagide [192, 193].
}

Its phytoecdysteroids are beneficial for correcting the

hyperglycaemia and preventing diabetic complications in liver, pancreas and kidneys in alloxan diabetic rats [191]. Acute and subchronic antihyperglycemic effects in normoglycemic and STZ-diabetic rats [194, 195].

\section{Other reported pharmacological effects}

Hypolipidemic and hypocholesterolemic activities that may reduce intestinal cholesterol absorption [195-200] as well as antiatherogenic efficacy [199]. Vasorelaxant effect in rat aorta [196]. Reducing the oxidative stress in hypercholesterolemic rats by increasing the antioxidant enzymes activity [200]. Antioxidative benefits [201]. Inhibits crystallization of calcium oxalate in the urine [202]. Insecticidal properties [203, 204].
Leguminoseae

Alhagi maurorum Medicus

(Decoction of roots [24])

Flavonoids (isorhamnetin-3-O-[- $\alpha-$

1-rhamnopyranosyl-(1 $\rightarrow 3)]-ß-D-$ glucopyranoside; 3'-O-

12 methylorobol and quercetin 3-Oß-D-glucopyranoside) [205, 206]; cinnamic acids, phenolic acids,

ß-sitosterol and its glucoside [205, 207]. Three flavones (2-phenyl1,4-benzopyrone derivatives) [208]. Polymethoxy substituted flavanenol [209] and triterpenoid lupeol [210]. Tannins and anthraquinones [211].
NONE

Antioxidative [206, 207, 212], anti-inflammatory [208, 210, 213, 214], antifungal [211] and antigastric ulcer [208, 214-216] activities. Antinociceptive [217] and antidiarrhoeal effects [218]. Spasmolytic and urether relaxing benefits [209, 219, 220]. ACE- and NADH oxidaseinhibitory activity [221]. Antibacterial activity [222]. Potent allelopathic activity [223]. 
Tab. 1. (Cont.)

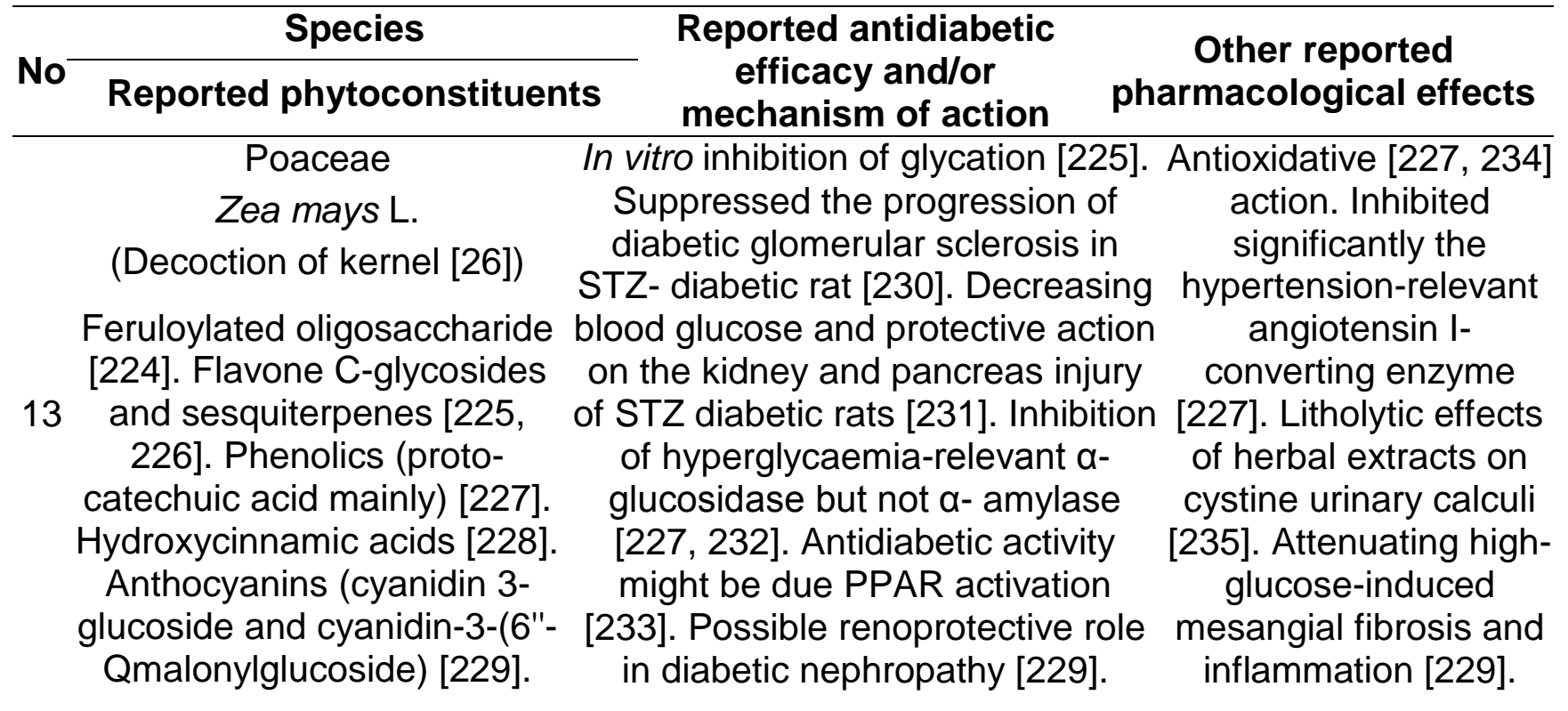

\section{Polygonaceae}

Rheum ribes Linn.

(Decoction of roots [23])

Tannins and hydroxyanthracene derivatives (rhein, physcion, aloe-

14 emodin, chrysophanol, physcion8-O-glucoside, aloe-emodin-8-Oglucoside, sennoside $A$, rhaponticin) [236, 237], minerals [238], phenolics (pyrocatechol) and flavonoids (quercetin equivalents) [239].

\section{Rhamnaceae}

Zizyphus spina- christi (L.) Desf.

(Infusion of fruits, leaves, bark [27])

15

Saponin glycosides [250252]. Flavonoids [253, 254].

Essential oil [255, 256].

Amino acid, carbohydrate and lipid composition [257, 258].
Antiviral [242] and

Insulin releasing effects in antibacterial activities [243] healthy mice [240] and with nutritional value [238]. hypoglycemic activity in Antioxidative potential [239, alloxan-diabetic animals 244, 245]. Cytotoxic effects [241]. Significant dose $\quad[246,247]$ and anti-ulcer dependent dual inhibition activity [248] as well as of $\alpha$-amylase and $\alpha$ - treating mild to moderate glucosidase in vitro [48]. major depression disorders [249].

Insulinotropic Its lipid fraction showed antimicrobial hypoglycaemic effects activity against Bacillus subtilis, in diabetic rats [251, Escherichia coli and Streptococcus 259, 260]. Antidiabetic pyogenes [257]. Its fruit and seed are effect in alloxan- good source of protein, mineral and diabetic dogs [261]. $\quad$ energy foods [258]. Antinociceptive effect in mice and rats [267, 268]. Antidiarrhoeal benefits [269]. Mild dose dependent CNS depressant effect [270]. Molluscicidal property [94]. 
Tab. 1. (Cont.)

\begin{tabular}{|c|c|c|c|}
\hline \multirow{2}{*}{$\mathrm{No}^{-}$} & Species & \multirow{2}{*}{$\begin{array}{l}\text { Reported antidiabetic } \\
\text { efficacy and/or } \\
\text { mechanism of action }\end{array}$} & \multirow{2}{*}{$\begin{array}{c}\text { Other reported } \\
\text { pharmacological effects }\end{array}$} \\
\hline & Reported phytoconstituents & & \\
\hline 16 & $\begin{array}{c}\text { Rosaceae } \\
\text { Alchemilla vulgaris L.(De } \\
\text { of leaves, roots [28 }\end{array}$ & $\begin{array}{cr}\text { Weight reduction } & \text { Antioxid } \\
\text { in obese } & \text { 275]. Mou } \\
\text { subjects [279] } & \text { properties } \\
\text { despite lack of } & \text { activi } \\
\text { antihyper- } & \text { myofibro } \\
\text { glycemic activity } & \text { of thyroi } \\
\text { in STZ diabetes } & \text { antimicr } \\
\text { mice [280]. } & 283,2\end{array}$ & $\begin{array}{l}273 \text {, } \\
\text { ealing } \\
\text { nitotic } \\
\text { id } \\
\text { vation } \\
272] \text {; } \\
277 \text {, } \\
\text { tic }\end{array}$ \\
\hline 17 & $\begin{array}{l}\text { Sarcopoterium spinosum (L.) } \\
\text { Spach. [Syn Poterium } \\
\text { spinosum L.] } \\
\text { (Infusion, decoction of roots } \\
{[13,24,27-29] \text { ) }}\end{array}$ & $\begin{array}{l}\text { Traditionally used in the } \\
\text { treatment of diabetes } \\
\text { [289].Hypoglycaemic effect, } \\
\text { evidenced in rabbits, with } \\
\text { fluctuations [290-292]. } \\
\text { Antidiabetic properties viz. } \\
\text { insulinotropic, and insulin } \\
\text { sensitizing [293, 294]. Starch } \\
\text { blocker due to duality of } \\
\text { inhibition of } \alpha \text {-amylase and } \alpha- \\
\text { glucosidase [48]. }\end{array}$ & $\begin{array}{l}\text { Action potential changes } \\
\text { induced by its polyflavane } \\
\text { on normal or hypoxic } \\
\text { guinea pig myocardial } \\
\text { strips [295]. Tumour } \\
\text { inhibitory effects [296] and } \\
\text { antioxidative properties } \\
\text { [43]. Inhibited } \\
\text { isoproterenol-induced } \\
\text { lipolysis in 3T3-L1 } \\
\text { adipocytes [293]. }\end{array}$ \\
\hline
\end{tabular}

Umbelliferae

Ferula persica Wild.

(Decoction of roots and resin $[23,30])$

Sesquiterpenes, persicasulphides $A, B$ and $C$ 18 and umbelliprenin [297-303]. Several coumarins (farnesiferol A, B, badrakemone, gummosin) and a new coumarin, farnesiferone A) [303, 304].

Sesquiterpene coumarin glycosides [305, 306].

Essential oil [307-310].
Did not demonstrate any $\alpha$-amylase inhibitory activity, thus lacking on significant hypoglycaemic effects in normoglycemic and STZ-hyperglycaemic Antigenotoxic activity via prevention of rats [46]. [299]. Antifungal activity [300]. Antioxidant, anti-inflammatory and lipoxygenase inhibitory properties and cancer preventive activity of umbelliferin [302, 303]. Farnesiferol A significantly inhibited the Pglycoprotein activity [305]. Antimicrobial effects [309]. oxidative damage to DNA of rat
Matrix metalloproteinases inhibition [297]. Umbelliprenin from F. persica roots inhibits the red pigment production in Serratia marcescens lymphocytes [311] as well as cytotoxicity [312]. Umbelliprenin induced apoptosis in CLL cell lines [313]. 
Tab. 1. (Cont.)

\begin{tabular}{|c|c|c|c|}
\hline & Species & Reported antidiabetic & \\
\hline & Reported phytoconstituents & $\begin{array}{c}\text { efficacy and/or } \\
\text { mechanism of action }\end{array}$ & pharm \\
\hline
\end{tabular}

Antidiabetic effect on high

fructose fed rats [324].

Alpha-amylase inhibitory activity [325].

Antihyperglycemia in

animal models via

reduction of intestinal

Urticaceae

Urtica dioica L.

(Decoction of herb [26])

glucose absorption [326]

and enhancement of insulin

secretion by Langerhans

Isletes [327] or inhibition of a-glucosidase [328].

Hypoglycemic and protective activities of $\beta$-cells of Langerhans in hyperglycemic rats [329]. Proliferation of the beta cells of the diabetic rats [330]. Chronic exposure (24 h) to U. dioica significantly enhanced glucose uptake in L6GLUT4myc myoblast cells [331]. Anti-hyperglycemic effect in STZ-rats via potentiating insulin activity, thus enhancing glucose

Polyphenolics [314-316]. Flavonoids [317-319]. Essential oil [320, 321]. Lignan glucosides [322]. Carotenoids [323].

\section{utilization [332] and \\ plausible activation of the} human peroxisome proliferator-activated receptor in glucose homeostasis [333]. Protective effect on hepatocytes of STZ rats [334], neuro-protective effect in diabetes-induced loss of pyramidal cells [335].
Antioxidant, antiradical, antimicrobial and antiulcerogenic effects [314316, 336]. Antimicrobial activity [337]. Promotes learning performance in the brain of rats [338]. Immunostimulatory activity of the flavonoid fraction and intracellular killing activity

of the isolated flavonoid glycosides suggesting that they could possibly be useful for treating patients suffering from neutrophil function deficiency and chronic granulomatous diseases [317].

Immunostimulatory activity

[317, 318, 339]. Cardiovascular effects like hypotensive responses, through a

vasorelaxing effect mediated by the release of endothelial NO and the opening of potassium channels, and through a negative inotropic action [340].

Beneficial for treatment of benign prostatic hyperplasia [341]. Platelet inhibitory activity [342]. Hepatoprotective in $\mathrm{CCl}_{4}$ treated rats [343] and protective effect on the liver in hepatic ischemia-reperfusion-injured rats [344]. Antifungal role [266].

Regulation of inflammatory gene expression [345]. Aromatase inhibitory activity [346]. 
Tab. 1. (Cont.)

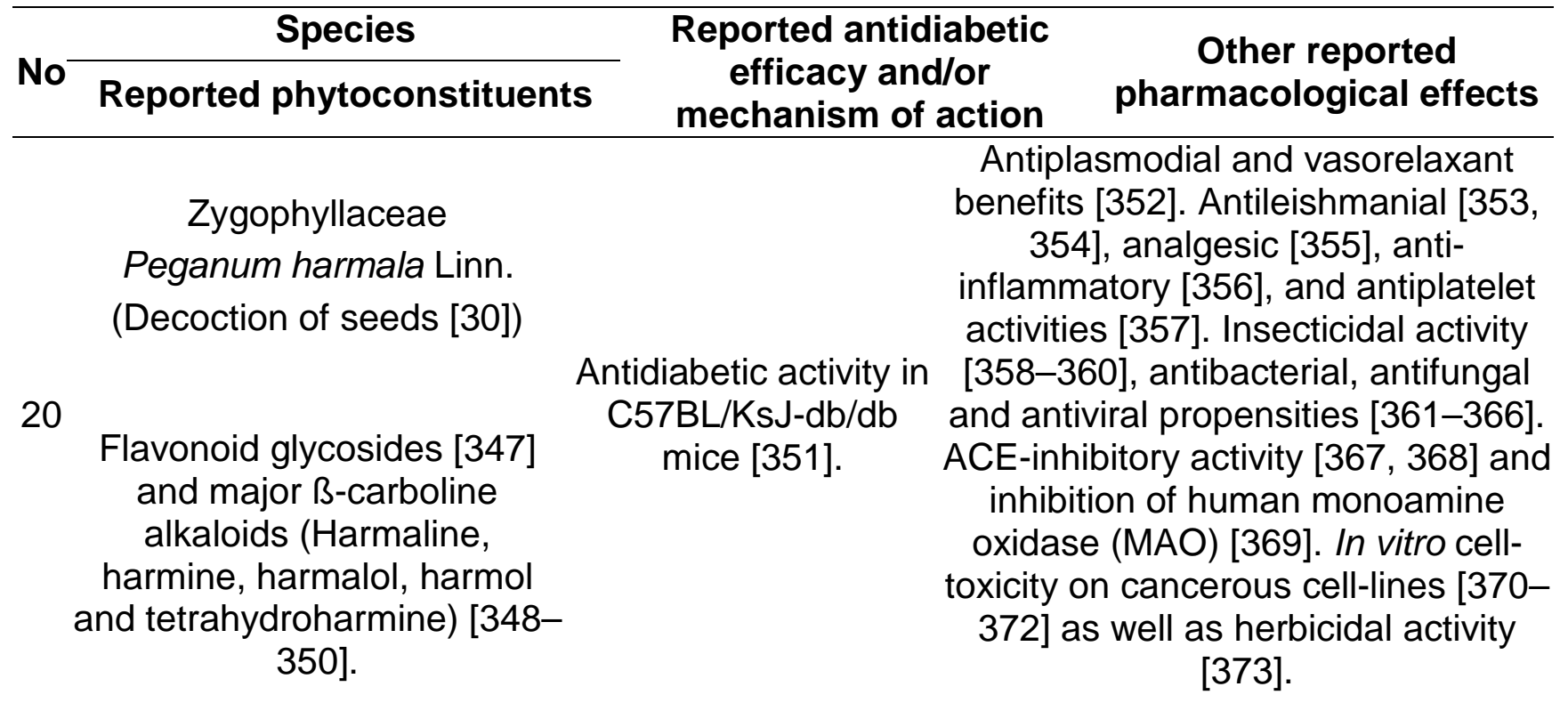

Six of the enlisted plants, namely Ajuga iva, Cleoma droserifolia, Urtica dioica, Sarcopoterium spinosum, Rheum ribes, Zea mays, and Geranium graveolens exhibited hypoglycemic activity in STZ and/ or alloxan diabetic animal models via inhibition of a-amylase and/or a-glucosidase or glucose absorption as plausible in vitro action mechanisms among many others (Table 1). On the other hand, neither in vivo nor in vitro bioactivity could be detected in antidiabetes pharmacology appraisals with Peganum harmala or Ferula persica. These findings strongly negate the claimed ethnotherapeutic uses promoted for these plant species. As for Varthemia iphionoides and Zizyphus spinachristi, the lack of complementary in vivo or in vitro testing necessitates further experimental design and verification on future accounts [56].

The hypoglycaemic properties of several classes of phytochemicals, including alkaloids, flavonoids, glycosides, glycolipids, polysaccharides, peptidoglycans, carbohydrates, amino acids, saponins, and terpenoids, have been exhaustively reported in the literature [37, 38, 57-60]. Additionally, it is well-accepted that certain herbs may alleviate considerably evident hyperglycaemia in clinical trials with well-characterised mechanisms of action $[61,62]$; their test results, however, are subject to multiple factors. Among which, different parts of an herb may have different ingredient profiles or different extraction methodologies may yield diverse active ingredients. In addition, each plant species contains multiple compounds, only a few of which may be therapeutically effective either alone or acting in synergism $[63,64]$. Hence, an urgent need exists for research proceedings in identifying the phytoconstituent(s) directly associated with hypoglycaemic/ antihyperglycemic bioactivity with equivalent assessments of the intra- and inter-species variations in secondary metabolites. Future research directives may also incur extensive clinical population-based studies for selected species. Moreover, investigating the combination formulations of natural products with synthetic drugs of complementary pharmacologies may determine the optimal and cost-effective therapies. Additionally, as herb-drug interactions in diabetic treatments/supplements have not been well-evidenced or 
documented [65], it is warranted that follow-up studies on their long-term side-effects be conducted. Subsequently, this may invite the potential development of food products fortified with clinically safe and effective plant extracts and possible downstream planning and incorporation into diabetic diets [66].

In conclusion, the reported findings, uniquely indicating the potential use of medicinal plants as antidiabetic agents, are among the very few that explored Jordanian flora from semi-arid and arid bioclimatic areas for pharmaceutical leads. Comprehensive research aiming at fully exploiting any of the promising species from the Jordanian flora, either alone or in combination with existing therapies, might lead to discovery of new avenues for medicinal plants/natural compounds in reducing the major public health impact of diabetes. Characterization of molecular targets and elucidation of relevant mechanisms of action also stand for another set of plausible requirements. Then, despite modern medicine accessibility, traditional medicine can be propagated as a viable health alternative.

\section{Authors' Statement}

\section{Competing Interests}

The authors declare no conflict of interest.

\section{References}

[1] Moore H, Summerbell C, Hooper L, Cruickshank K, Vyas A, Johnstone P, Ashton V, Kopelman P. Dietary advice for treatment of type 2 diabetes mellitus in adults.

The Cochrane database of systemic reviews. 2004; (2): CD004097. http://www.ncbi.nlm.nih.gov/pubmed/15106237

[2] Wild S, Roglic G, Green A, Sicree R, King H.

Global prevalence of diabetes: Estimates for the year 2000 and projections for 2030.

Diabetes Care. 2004; 27: 1047-1053.

http://dx.doi.org/10.2337/diacare27.5.1047

[3] World Health Organization.

WHO Publications.

2011; Fact Sheet No 312.

[4] Dababneh F, Asad M, Abu Diab A.

Information and Research Newsletter, Issue 1, Mortality data in Jordan 2007.

Ministry of Health, Jordan; 2010.

[5] International Diabetes Federation (IDF 2009).

IDF Diabetes Atlas $4^{\text {th }}$ Edition, Prevalence estimates of diabetes mellitus (DM), $2010-$ MENA. IDF [Online].

http://www.diabetesatlas.org/content/prevalence-estimates-diabetes-mellitus-dm-2010

[Accessed on 10 April 2011]

[6] Bulatova NR, Yousef AF, AbuRuz SM.

Antiplatelet therapy for primary and secondary prevention in Jordanian patients with diabetes mellitus.

Thromb Res. 2007; 121: 43-50.

http://dx.doi.org/10.1016/j.thromres.2007.03.006

[7] Ajlouni K, Khader YS, Batieha A, Ajlouni H, El-Khateeb M.

An increase of diabetes mellitus in Jordan over 10 years.

J Diabetes Complicat. 2008; 22: 317-324.

http://dx.doi.org/10.1016/j.jdiacomp.2007.01.004 
[8] Zindah M, Belbeisi A, Walke H, Mokdad AH.

Obesity and diabetes in Jordan: Findings from the behavioral risk factor surveillance system, 2004.

Prev Chronic Dis. 2008; 5: 1-8.

http://www.ncbi.nlm.nih.gov/pubmed/18082006/

[9] Al-Eisawi D, El-Oqlah A, Al-Khader IA; eds.

Jordan Country Study on Biological Diversity.

United Nations Environmental Program.

Al-Rai Commercial Press, Amman, pp. 7-11, 2000.

[10] Al-Eisawi DM.

List of Jordan vascular plants.

Mitt Bot Staatssamml Münch. 1982; 18: 79-182.

[11] Al-Eisawi DM.

Vegetation of Jordan.

UNESCO- Regional Office for Science and Technology for the Arab States, Cairo, pp. 266, 1996.

[12] Al-Eisawi DMH.

Field guide to wild flowers of Jordan and neighbouring countries.

Commercial Press, Jordan Press foundation Al-Rai, Amman, pp.4-8, 1998.

[13] Al-Khalil S.

A survey of plants used in Jordanian traditional medicine.

Int J Pharmacog. 1995; 33: 317-323.

[14] Azaizeh H, Fulder S, Khalil K, Said O.

Ethnobotanical knowledge of local Arab practitioners in the Middle Eastern region.

Fitoterapia. 2003; 74: 98-108.

http://dx.doi.org/10.1016/S0367-326X(02)00285-X

[15] Bonet MA, Valles J.

Use of non-crop food vascular plants in Montseny biosphere reserve (Catalonia, Iberian Peninsula).

Int J Food Sci Nutr. 2002; 53: 225-248.

http://dx.doi.org/10.1080/09637480220132841

[16] Butler MS.

The role of natural product chemistry in drug discovery.

J Nat Prod. 2004; 67: 2141-2153.

http://dx.doi.org/10.1021/np040106y

[17] Goldman P.

Herbal medicines today and the roots of modern pharmacology.

Annals Int Med. 2001; 135: 594-600.

http://dx.doi.org/10.7326/0003-4819-135-8_Part_1-200110160-00010

[18] Phillipson JD.

Phytochemistry and medicinal plants.

Phytochemistry. 2001; 56: 237-243.

http://dx.doi.org/10.1016/S0031-9422(00)00456-8

[19] Newman DJ, Cragg GM, Snader KM.

Natural products as sources of new drugs over the period 1981-2001.

J Nat Prod. 2003; 66: 1022-1037.

http://dx.doi.org/10.1021/np030096l

[20] Abu-Rabia A.

Herbs as a food and medicine source in Palestine.

Asian Pac J Cancer Prev. 2005; 6: 404-407.

http://www.ncbi.nlm.nih.gov/pubmed/16236008 
[21] Wazaify M, Afifi FU, El-Khateeb M, Ajlouni K.

Complementary and alternative medicine use among Jordanian diabetes patients.

Complement Ther Clin Pract. 2011; 17: 71-75.

http://dx.doi.org/10.1016/j.ctcp.2011.02.002

[22] Al-Aboudi A, Afifi FU.

Plants used for the treatment of diabetes in Jordan: A review of scientific evidence.

Pharm Biol. 2011; 49: 221-239.

http://dx.doi.org/10.3109/13880209.2010.501802

[23] Abu Irmaileh B, Afifi F.

Treatment with medicinal plants in Jordan.

Dirasat. 2000; 27: 53-74.

[24] Oran SA, Al-Eisawi DM.

Check list of medicinal plants in Jordan.

Dirasat. 1998; 25: 84-112.

[25] Hudaib M, Mohammad M, Bustanji Y, Tayyem R, Yousef M, Abuirjeie M, Aburjai T.

Ethnopharmacological survey of medicinal plants in Jordan, Mujib Nature Reserve and surrounding area.

J Ethnopharmacol. 2008; 120: 63-71.

http://dx.doi.org/10.1016/j.jep.2008.07.031

[26] Otoom SA, Al-Safi SA, Kerem ZK, Alkofahi A.

The use of medicinal herbs by diabetic Jordanian patients.

J Herb Pharmacother. 2006; 6: 31-41.

http://dx.doi.org/10.1080/J157v06n02_03

[27] Said O, Khalil K, Fulder S, Azaizeh $\mathrm{H}$.

Ethnopharmacological survey of medicinal herbs in Israel, the Golan Heights and the West Bank region.

J Ehnopharmacol. 2002; 83: 251-265.

http://dx.doi.org/10.1016/S0378-8741(02)00253-2

[28] Aburjai T, Hudaib M, Tayyem R.

Ethnopharmacological survey of medicinal herbs in Jordan, the Ajloun Height region.

J Ethnopharmacol. 2007; 110: 294-304.

http://dx.doi.org/10.1016/j.jep.2006.09.031

[29] Dafni A, Yaniv Z, Palevitch Z.

Ethnobotanical survey of medicinal plants in northern Israel.

J Ethnopharmacol. 1984; 10: 295-310.

http://dx.doi.org/10.1016/0378-8741(84)90017-5

[30] Lev E, Amar Z.

Ethnopharmacological survey of traditional drugs sold in Israel at the end of the 20th century.

J Ethnopharmacol. 2000; 72: 191-205.

http://dx.doi.org/10.1016/S0378-8741(00)00230-0

[31] Camejo-Rodrigues J, Ascensao L, Bonet MA, Valles J.

An ethnobotanical study of medicinal and aromatic plants in the Natural Park of "Serra de Sao

Mamede" (Portugal).

J Ethnopharmacol. 2003; 89: 199-209.

http://dx.doi.org/10.1016/S0378-8741(03)00270-8

[32] Jeambey Z, Johns T, Talhouk S, Batal M.

Perceived health and medicinal properties of six species of wild edible plants in north-east Lebanon.

Pub Health Nutr. 2009; 12: 1902-1911.

http://dx.doi.org/10.1017/S1368980009004832 
[33] Afifi-Yazar FU, Kasabri V, Abu-Dahab R.

Medicinal plants from Jordan in the treatment of diabetes: Traditional uses vs. in vitro and in vivo evaluations; Mini-review.

Planta Med. 2011; 77: 1210-1220.

http://dx.doi.org/10.1055/s-0031-1279983

[34] Aly HF, Ebrahim ME, Metawaa HM, Hosni EAA, Ebrahim FM.

In vitro and in vivo evaluation of the antidiabetic effect of different extracts of Nepeta cataria in streptozotocin induced diabetic rats.

J Am Sci. 2010; 6: 364-386.

[35] Afifi FU, Abu Irmaileh B.

Herbal medicine in Jordan with special emphasis on less commonly used medicinal herbs.

J Ethnopharmacol. 2000; 72: 101-110.

http://dx.doi.org/10.1016/S0378-8741(00)00215-4

[36] Abu Irmaileh BE, Afifi FU.

Herbal medicine in Jordan with special emphasis on commonly used herbs.

J Ethnopharmacol. 2003; 89: 193-197.

http://dx.doi.org/10.1016/S0378-8741(03)00283-6

[37] Mukherjee PK, Maiti K, Mukherjee K, Houghton PJ.

Leeds from Indian medicinal plants with hypoglycaemic potentials.

J Ethnopharmacol. 2006; 106: 1-28.

http://dx.doi.org/10.1016/j.jep.2006.03.021

[38] Prabhakar PK, Doble M.

A target based therapeutic approach towards diabetes mellitus using medicinal plants.

Curr Diabetes Rev. 2008; 4: 291-308.

http://dx.doi.org/10.2174/157339908786241124

[39] Hui H, Tang G, Go VLW.

Hypoglycaemic herbs and their action mechanisms.

Chinese Med. 2009; 4: 11-21.

http://dx.doi.org/10.1186/1749-8546-4-11

[40] Gharaibeh MN, Elayan HH, Salhab AS.

Hypoglycaemic effects of Teucrium polium.

J Ethnopharmacol. 1988; 24: 93-99.

http://dx.doi.org/10.1016/0378-8741(88)90139-0

[41] Nusier MK, Bataineh HN, Bataineh ZM, Daradka HM.

Effects of Ballota nigra on glucose and insulin in alloxan-diabetic albino rats.

Neuro Endocrinol Lett. 2007; 28: 470-472.

http://www.ncbi.nlm.nih.gov/pubmed/17627273

[42] Irshaid F, Mansi K, Aburjai T.

Antidiabetic effect of essential oil from Artemisia sieberi growing in Jordan in normal and alloxan induced diabetic rats.

Pak J Biol Sci. 2010; 13: 423-430.

http://dx.doi.org/10.3923/pjbs.2010.423.430

[43] Al-Mustafa AH, Al-Thunibat OY.

Antioxidant capacity of some Jordanian medicinal plants used traditionally for the treatment of diabetes.

Pak J Biol Sci. 2008; 1: 351-358.

http://www.ncbi.nlm.nih.gov/pubmed/18817155

[44] Qa'dan F, Verspohl EJ, Nahrstedt A, Petereit F, Matalka KZ.

Cinchonain Ib isolated from Eriobotrya japonica induces insulin secretion in vitro and in vivo.

J Ethnopharmacol. 2009; 124: 224-227.

http://dx.doi.org/10.1016/j.jep.2009.04.023 
[45] Abu-Zaiton AS.

Anti-diabetic activity of Ferula asafoetida extract in normal and alloxan-induced diabetic rats.

Pak J Biol Sci. 2010; 13: 97-100.

http://dx.doi.org/10.3923/pjbs.2010.97.100

[46] Hamdan II, Afifi FU.

Studies on the in vitro and in vivo hypoglycaemic activities of some medicinal plants used in treatment of diabetes in Jordanian traditional medicine.

J Ethnopharmacol. 2004; 93: 117-121.

http://dx.doi.org/10.1016/j.jep.2004.03.033

[47] Afifi F, Al-Khalidi B, Khalil E.

Studies on the in vivo hypoglycaemic activities of two medicinal plants used in the treatment of diabetes in Jordanian traditional medicine following intranasal administration.

J Ethnopharmacol. 2005; 100: 314-318.

http://dx.doi.org/10.1016/j.jep.2005.03.016

[48] Kasabri V, Afifi FU, Hamdan I.

In vitro and in vivo acute antihyperglycemic effects of five selected indigenous plants from Jordan used in traditional medicine.

J Ethnopharmacol. 2011a; 133: 888-896.

http://dx.doi.org/10.1016/j.jep.2010.11.025

[49] Kasabri V, Afifi FU, Hamdan I.

Evaluation of the acute antihyperglycemic effects of four selected indigenous plants from Jordan used in traditional medicine.

Pharm Biol. 2011b; 49: 687-695.

http://dx.doi.org/10.3109/13880209.2010.539619

[50] Rauter AP, Martins A, Borges C, Mota-Filipe H, Pinto R, Sepodes B, Justino J.

Antihyperglycaemic and protective effects of flavonoids on streptozotocin-induced diabetic rats.

Phytother Res. 2010; 24: S133-S138.

http://dx.doi.org/10.1002/ptr.3017

[51] Yazdanparast R, Ardestani A, Jamshini S.

Experimental diabetes treated with Achillea santolina: Effects on pancreatic oxidative parameters.

J Ethnopharmacol. 2007; 112: 13-18.

http://dx.doi.org/10.1016/j.jep.2007.01.030

[52] Srivatsan R, Das S, Gadde R, Manoj-Kumar K, Taduri S, Rao N, Ramesh B, Baharani A, Shah K, Kamireddy SC, Priyatham G, Balakumaran TA, Balakumaran SS, Kamath A, Rao A.

Antioxidants and lipid peroxidation status in diabetic patients with and without complications.

Arch Iran Med. 2009; 12: 121-127.

[53] Ramalho-Santos J, Amaral S, Oliveira PJ.

Diabetes and the impairment of reproductive function: possible role of mitochondria and reactive oxygen species.

Curr Diabetes Rev. 2008; 4: 46-54.

http://dx.doi.org/10.2174/157339908783502398

[54] Chung MJ, Cho SY, Bhuiyan MJ, Kim KH, Lee SJ.

Anti-diabetic effects of lemon balm (Melissa officinalis) essential oil on glucose- and lipid-regulating enzymes in type 2 diabetic mice.

Br J Nutr. 2010; 104: 180-188.

http://dx.doi.org/10.1017/S0007114510001765

[55] Basak SS, Candan F.

Chemical composition and in vitro antioxidant and antidiabetic activities of Eucalyptus camaldulensis

Dehn. essential oil.

J Iran Chem Soc. 2010; 7: 216-226.

http://dx.doi.org/10.1007/BF03245882 
[56] Marles RJ, Farnsworth NR.

Antidiabetic plants and their active constituents.

Phytomedicine. 1995; 2: 137-189.

http://dx.doi.org/10.1016/S0944-7113(11)80059-0

[57] Benalla W, Bellahcen S, Bnouham M.

Antidiabetic medicinal plants as a source of alpha glucosidase inhibitors.

Curr Diab Rev. 2010; 6: 247-254.

http://dx.doi.org/10.2174/157339910791658826

[58] Qi LW, Liu EH, Chu C, Peng YB, Cai HX, Li P.

Anti-diabetic agents from natural products- an update from 2004-2009.

Curr Top Med Chem. 2010; 10: 434-457.

http://dx.doi.org/10.2174/156802610790980620

[59] Bedekar A, Shah K, Koffas M.

Natural products for type II diabetes treatment.

Adv Appl Microbiol. 2010; 71: 21-73.

http://dx.doi.org/10.1016/S0065-2164(10)71002-9

[60] Dinda B, Debnath S, Mohanta BC, Harigaya Y.

Naturally occurring triterpenoid saponins.

Chem Biodivers. 2010; 7: 2327-2580.

http://dx.doi.org/10.1002/cbdv.200800070

[61] Yin J, Zhang $\mathrm{H}$, Ye J.

Traditional Chinese medicine in treatment of metabolic syndrome.

Endocr Metab Immun Disord Drug Targets. 2008; 8: 99-111.

http://dx.doi.org/10.2174/187153008784534330

[62] Kuriyan R, Rajendran R, Bantwal G, Kurpad AV.

Effect of supplementation of Coccinia cordifolia extract on newly defected diabetic patients.

Diabetes Care. 2008; 31: 216-220.

http://www.ncbi.nlm.nih.gov/pubmed/18000183

[63] Angelova N, Kong HW, Heijden R van der, Yang SY, Choi YM, Kim HK, Wang M, Hankemeir, Greef J van der, Xu G, Verpoorte R.

Recent methodology in the phytochemical analysis of ginseng.

Phytochem Anal. 2008; 19: 2-16.

http://dx.doi.org/10.1002/pca.1049

[64] Shan JJ, Rodgers K, Lai CT, Sutherland SK.

Challenges in natural health product research: The importance of standardization.

Proc West Pharmacol Soc. 2007; 50: 24-30.

http://www.ncbi.nlm.nih.gov/pubmed/18605225

[65] Xu H, Williams KM, Liauw WS, Murray M, Day RO, McLachlan AJ.

Effects of St John's wort and CYP2C9 genotype on the pharmacokinetics and pharmacodynamics of gliclazide.

Br J Pharmacol. 2008; 153: 1579-1586.

http://dx.doi.org/10.1038/sj.bjp.0707685

[66] Mentreddy SR.

Medicinal plant species with potential antidiabetic properties.

J Sci Food Agric. 2007; 87: 743-750.

http://dx.doi.org/10.1002/jsfa.2811

[67] Shalaby AF, Richter G.

Chromatographic investigation of the essential oil of Achillea fragrantissima.

J Pharm Sci. 1964; 53: 1502-1505.

http://dx.doi.org/10.1002/jps.2600531215 
[68] Shalaby AF, Steinegger E.

[The phytochemical study Achillea fragrantissima (Forsk.) Sch. Bip].

Pharm Acta Helv. 1964; 39: 756-761.

http://www.ncbi.nlm.nih.gov/pubmed/14347174

[69] Shalaby AF, Tsingarida K, Steinegger E.

[On the flavonoids from Achillea fragrantissima (Forsk.) Sch. Bip].

Pharm Acta Helv. 1965; 40: 19-24.

http://www.ncbi.nlm.nih.gov/pubmed/5858665

[70] el-Shazly AM, Hafez SS, Wink M

Comparative study of the essential oils and extracts of Achillea fragrantissima (Forssk.) Sch. Bip. and Achillea santolina L. (Asteraceae) from Egypt.

Pharmazie. 2004; 59: 226-230.

http://www.ncbi.nlm.nih.gov/pubmed/15074599

[71] Ageel AM, Mossa JS, Al-Yahya MA, Al-Said MS, Tariq M.

Experimental studies on antirheumatic crude drugs used in Saudi traditional medicine.

Drugs Exp Clin Res. 1989; 15: 369-372.

http://www.ncbi.nlm.nih.gov/pubmed/2598777

[72] Barel S, Segal R, Yashphe J.

The antimicrobial activity of the essential oil from Achillea fragrantissima.

J Ethnopharmacol. 1991; 33: 187-191.

http://dx.doi.org/10.1016/0378-8741(91)90177-F

[73] Omar SS.

Inhibitory effect of nisin and some of plant extracts against growth of Cronobacter sakazakii in reconstituted infant milk formula.

Health Env Res Online 2011; 66: 389-393.

[74] Soltan MM, Zaki AK.

Antiviral screening of forty-two Egyptian medicinal plants.

J Ethnopharmacol. 2009; 126: 102-107

http://dx.doi.org/10.1016/j.jep.2009.08.001

[75] Mustafa EH, Abu Zarga M, Abdalla S.

Effects of cirsiliol, a flavone isolated from Achillea fragrantissima, on rat isolated ileum.

Gen Pharmacol. 1992; 23: 555-560.

http://dx.doi.org/10.1016/0306-3623(92)90127-6

[76] Elmann A, Mordechay S, Erlank H, Telerman A, Rindner M, Ofir R.

Anti-Neuroinflammatory effects of the extract of Achillea fragrantissima.

BMC Complement Altern Med. 2011; 11: 98.

http://dx.doi.org/10.1186/1472-6882-11-98

[77] Sathiyamoorthy P, Lugasi-Evgi H, Schlesinger P, Kedar J, Gopas J, Pollack Y, Golan-Goldhirsh A. Screening for cytotoxic and antimalarial activities in desert plants of the Negev and Bedouin market plant products.

Pharm Biol. 1999; 37: 188-195.

http://dx.doi.org/10.1076/phbi.37.3.188.6298

[78] Sathiyamoorthy P, Lugasi-Evgi H, Van-Damme P, Abu-Rabia A, Gopas J, Golan-Goldhrish A. Larvicidal activity in desert plants of the Negev and Bedouin market plant products.

Pharm Biol. 1997; 35: 265-273.

http://dx.doi.org/10.1076/phbi.35.4.265.13314

[79] Khafagy SM, Tosson S.

Crystallographic, optical and chromatographic studies of judaicin, bitter principle of Artemisia judaica L.

Planta Med. 1968; 16: 446-449.

http://dx.doi.org/10.1055/s-0028-1099933 
[80] Urmanova FF, Komilov KM.

Flavonoids of Achillea santolina.

Chem Nat Comp. 1999; 35: 214.

http://dx.doi.org/10.1007/BF02234939

[81] Ahmad VU, Khan MA, Baqal FT, Tareen RB.

Santoflavone, A 5-deoxyflavonoid from Achillea santolina.

Phytochemistry. 1995; 38: 1305-1307.

http://dx.doi.org/10.1016/0031-9422(94)00785-R

[82] Balboul BAAA, Ahmed AA, Otsuka H, Bando M, Kido M, Takeda Y.

A guaianolide and a germacranolide from Achillea santolina.

Phytochemistry. 1997; 46: 1045-1049.

http://dx.doi.org/10.1016/S0031-9422(97)00389-0

[83] Ardestani A, Yazdanparast R.

Antioxidant and free radical scavenging potential of Achillea santolina extracts.

Food Chem. 2007; 104: 21-29.

http://dx.doi.org/10.1016/j.foodchem.2006.10.066

[84] Hasani-Ranjbar S, Larijani B, Abdollahi M.

A systematic review of Iranian medicinal plants useful in diabetes mellitus.

Arch Med Sci. 2008; 4: 285-292.

[85] Darwish RM, Aburjai TA.

Effect of ethnomedicinal plants used in folklore medicine in Jordan as antibiotic resistant inhibitors on Escherichia coli.

BMC Complement Altern Med. 2010; 10: 9.

http://dx.doi.org/10.1186/1472-6882-10-9

[86] Khalil A, Dababneh BF, Al-Gabbiesh AH.

Antimicrobial activity against pathogenic microorganisms by extracts from herbal Jordanian plants.

J Food Agric Env. 2009; 7: 103-106.

[87] Zaringhalam J, Akbari A, Tekieh E, Manaheji H, Rezazadeh S.

Achillea santolina reduces serum interleukin-6 level and hyperalgesia during complete Freund's adjuvant-induced inflammation in male Wistar rats.

Zhong Xi Jie He Xue Bao. 2010; 8: 1180-1189.

http://dx.doi.org/10.3736/jcim20101211

[88] Abdallah OM, Ali AA, Itokawa $\mathrm{H}$.

Cytotoxic activity of sesquiterpene lactones, isolated from Ambrosia maritima.

Pharmazie. 1991; 46: 472.

http://www.ncbi.nlm.nih.gov/pubmed/1763132

[89] Abdelgaleil SAM, Badawy MEI, Suganuma T, Kitahara K.

Antifungal and biochemical effects of pseudoguaianolide sesquiterpenes isolated from Ambrosia maritima L.

Afr J Micr Res. 2011; 5: 3385-3393.

[90] Mahmoud AA, Ahmed AA, El Bassuony AA.

A new chlorosesquiterpene lactone from Ambrosia maritima.

Fitoterapia. 1999; 70: 575-578.

http://dx.doi.org/10.1016/S0367-326X(99)00091-X

[91] AbouZid S, Orihara Y.

Biosynthesis of polyacetylenes in Ambrosia maritima hairy roots.

Planta Med. 2007; 73: 1327-1329.

http://dx.doi.org/10.1055/s-2007-981616

[92] Abdel-Hamid AZ.

Development of bait formulations for control of intermediate hosts of African schistosome species.

J Appl Toxicol. 1997; 17: 391-395.

http://dx.doi.org/10.1002/(SICl)1099-1263(199711/12)17:6<391::AID-JAT456>3.0.CO;2-I 
[93] El-Ansary A, Mohamed AM, Mahmoud SS, El-Bardicy S.

On the pathogenicity of attenuated Schistosoma mansoni cercariae released from metabolically disturbed Biomphalaria alexandrina.

J Egypt Soc Parasitol. 2003; 33: 777-794.

[94] Shams KA, Abou-Setta LM, Radwan HM.

Molluscicidal activity and screening of forty Egyptian medicinal plants and determination of the active fractions.

Asian J Chem 2012; 24: 3548-3552.

[95] Greerts S, Van Blerk K, Triest L.

Effect of Ambrosia maritima on Anopheles stephensi and Aedes aegypti.

J Ethnopharmacol. 1994; 42: 7-11.

http://dx.doi.org/10.1016/0378-8741(94)90016-7

[96] Greerts S, Belot J, Sabbe F, Triest L, Sidhom M.

Ambrosia maritima: effects on molluscs and non-target organisms.

J Ethnopharmacol. 1991; 33: 1-12.

http://dx.doi.org/10.1016/0378-8741(91)90153-5

[97] El-Ela NA, Talha M, Al-Aziz AA.

Response and effect of two plant crude extracts on mosquito larvae Culex pipiens.

J Egypt Public Health Assoc. 1998; 73: 649-665.

http://www.ncbi.nlm.nih.gov/pubmed/17217029

[98] Barakat R, Farghaly A, el-Sawy MF, Soliman NK, Duncan J, Miller FD.

An epidemiological assessment of Ambrosia maritima on the transmission of schistosomiasis in the Egyptian Nile Delta.

Trop Med Parasitol. 1993; 44: 181-186.

http://www.ncbi.nlm.nih.gov/pubmed/8256093

[99] Ahmed MB, Khater MR.

Evaluation of the protective potential of Ambrosia maritima extract on acetaminophen- induced liver damage.

J Ethnopharmacol. 2001; 75: 169-174.

http://dx.doi.org/10.1016/S0378-8741(00)00400-1

[100] Saleh MM, Rizk AM.

Flavonoids and coumarins of Anthemis pseudocotiola.

Planta Med. 1974; 25: 60-62.

http://dx.doi.org/10.1055/s-0028-1097913

[101] Kilic O, Kocak A, Bagci E.

Composition of the volatile oils of two Anthemis L. taxa from Turkey.

Z Naturforsch C. 2011; 66: 535-540.

http://dx.doi.org/10.5560/ZNC.2011.66c0535

[102] El-Ela MA, Jakupovic J, Bohlmann F, Ahmed AA, Seif El-Din A, Khafagi S, Sabri N, El- Ghazouly M. Seco-germacranolides from Anthemis pseudocotula.

Phytochemistry. 1990; 29: 2704-2706.

http://dx.doi.org/10.1016/0031-9422(90)85221-Z

[103] Vukovic I, Vujisic L, Vajs V,Tesevic V, Macura S, Janackovic P, Milosavljevic S.

Sesquiterpene lactones from the aerial parts of Anthemis arvensis L.

Biochem Syst Ecol. 2006; 34: 303-309.

http://dx.doi.org/10.1016/j.bse.2005.09.007

[104] Al-Dabbas MM, Hashinaga F, Abdelgaleil SA, Suganuma T, Akiyama K, Hayashi H.

Antibacterial activity of an eudesmane sesquiterpene isolated from common Varthemia, Varthemia iphionoides.

J Ethnopharmacol. 2005; 97: 237-240.

http://dx.doi.org/10.1016/j.jep.2004.11.007 
[105] Al-Dabbas MM, Suganuma T, Kitahara K, Hou DX, Fujii M.

Cytotoxic, antioxidant and antibacterial activities of Varthemia iphionoides Boiss. extracts.

J Ethnopharmacol. 2006; 108: 287-293.

http://dx.doi.org/10.1016/j.jep.2004.11.007

[106] Afifi FU, Al-Khalil S, Abdul-Haq BK, Mahasneh A, Al-Eisawi DM, Sharaf M, Wong LK, Schiff Jr PL. Antifungal flavonoids from Varthemia iphionoides.

Phytother Res. 1991; 5: 173-175.

http://dx.doi.org/10.1002/ptr.2650050407

[107] Al-Dabbas MM, Al-Ismail K, Abu-Taleb R, Hashimoto F, Rabah IO, Kitahara K, Fujita K, Suganuma T. Chemistry and antiproliferative activities of 3-methoxyflavones isolated from Varthemia iphionoides.

Chem Nat Comp. 2011; 47: 17-21.

http://dx.doi.org/10.1007/s10600-011-9821-8

[108] Avato P, Raffo F, Aldouri NA, Vartanian ST.

Essential oils of Varthemia iphionoides from Jordan.

Flav Frag J. 2004; 19: 559-561.

http://dx.doi.org/10.1002/ffj.1351

[109] Tamir H, Satovic Z, Gorelick J, Gorelick J, Danin A, Fischer R, Chaimovitsh D, Dudai N. Intraspecific variation of Chiliadenus iphionoides essential oil in Israel.

Chem Biodivers. 2011; 8: 1065-1082.

http://dx.doi.org/10.1002/cbdv.201000335

[110] Al-Dabbas MM, Kitahara K, Suganuma T, Hashimoto F, Tadera K.

Antioxidant and alpha-amylase inhibitory compounds from aerial parts of Varthemia iphionoides Boiss. Biosci Biotechnol Biochem. 2006; 70: 2178-2184.

http://dx.doi.org/10.1271/bbb.60132

[111] Afifi F, Saket M, Jaghabir M, Al-Eisawi D.

Effect of Varthemia iphionoides on blood glucose level of normal rats and rats with streptozocininduced diabetes mellitus.

Curr Ther Res. 1997; 58: 888-892.

http://dx.doi.org/10.1016/S0011-393X(97)80055-0

[112] Gorelick J, Kitron A, Pen S, Rosenzweig T, Madar Z.

Anti-diabetic activity of Chiliadenus iphionoides.

J Ethnopharmacol. 2011; 137: 1245-1249.

http://dx.doi.org/10.1016/j.jep.2011.07.051

[113] Afifi F, Aburjai T.

Antiplatelet activity of Varthenmia iphionoides.

Fitoterapia. 2004; 75: 629-633.

http://dx.doi.org/10.1016/j.fitote.2004.04.014

[114] Al-Abbas MM, Al-Ismail K, Al-Qudah YH.

Antioxidant activity of different extracts from Varthemia iphionoides.

Rivista Italiana delle Sostanze Grasse. 2010; 87: 243-249.

[115] Harlev E, Nevo E, Lansky EP, Lansky S, Bishayee A.

Anticancer attributes of desert plants: a review.

Anticancer Drugs. 2012; 23: 255-271.

http://dx.doi.iorg/10.1097/CAD.0b013e32834f968c

[116] Abu-Hijleh A, Jarrar N, Adwan K.

Antibacterial activity of common Varthemia, Varthemia iphionoides ethanol extract alone and in combination with cefotaxine.

Adv Biol Res. 2009; 3: 144-147.

[117] Fushiya S, Kishi Y, Hattori K, Batkhuu J, Takano F, Singab AN, Okuyama T.

Flavonoids from Cleome droserifolia suppress NO production in activated macrophages in vitro.

Planta Med. 1999; 65: 404-407.

http://dx.doi.org/10.1055/s-1999-14084 
[118] El-Askary HI.

Terpenoids from Cleome droserifolia (Forssk.) Del.

Molecules. 2005; 31: 971-977.

http://www.ncbi.nlm.nih.gov/pubmed/18007365

[119] Abdel-Kader MS, Alqasoumi SI, Al-Taweel AM.

Hepatoprotective constituents from Cleome droserifolia.

Chem Pharm Bull (Tokyo). 2009; 57: 620-624.

http://dx.doi.org/10.1248/cpb.57.620

[120] Aboushoer MI, Fathy HM, Abdel-Kader MS, Goetz G, Omar AA.

Terpenes and flavonoids from an Egyptian collection of Cleome droserifolia.

Nat Prod Res. 2010; 24: 687-696.

http://dx.doi.org/10.1080/14786410903292433

[121] El Naggar EMB, Bartošíková L, Žemlička M, Švajdlenka E, Rabišková M, Strnadová V, Nečas J. Antidiabetic Effect of Cleome droserifolia Aerial Parts: Lipid peroxidation-induced oxidative stress in diabetic rats.

Acta Vet. Brno. 2005; 74: 347.

http://dx.doi.org/10.2754/avb200574030347

[122] Ezzat SM, Motaal AA.

Isolation of new cytotoxic metabolites from Cleome droserifolia growing in Egypt.

Z Naturforsch C. 2012; 67: 266-274.

http://dx.doi.org/10.5560/ZNC.2012.67c0266

[123] Nicola WG, Ibrahim KM, Mikhail TH, Girgis RB, Khadr ME.

Role of the hypoglycemic plant extract Cleome droserifolia in improving glucose and lipid metabolism and its relation to insulin resistance in fatty liver.

Boll Chim Farm. 1996; 135: 507-517.

http://www.ncbi.nlm.nih.gov/pubmed/9035562

[124] El-Khawaga OY, Abou-Seif MA, El-Waseef A, Negm AA.

Hypoglycemic, hypolipidemic and antioxidant activities of Cleome droserifolia in streptozotocindiabetic rats.

J Stress Phys Biochem. 2010; 6: 28-41.

[125] El-Shenawy NS, Abdel-Nabi IM.

Hypoglycemic effect of Cleome droserifolia ethanolic leaf extract in experimental diabetes, and on non-enzymatic antioxidant, glycogen, thyroid hormone and insulin levels.

Diabetologia Croat. 2006; 35: 15-22.

[126] El-Shenawy NS, Soliman MF, Abdel-Nabi IM.

Does Cleome droserifolia have anti-schistosomiasis mansoni activity?

Rev Inst Med Trop Sao Paulo. 2006; 48: 223-228.

http://dx.doi.org/10.1590/S0036-46652006000400010

[127] Saad B, Dakwar S, Said O, Abu-Hijleh G, Al Battah F, Kmeel A, Aziazeh H.

Evaluation of medicinal plant hepatotoxicity in co-cultures of hepatocytes and monocytes.

Evid Based Complement Alternat Med. 2006; 3: 93-98.

http://dx.doi.org/10.1093/ecam/nel002

[128] Villaseñor IM, Lemon P, Palileo A, Bremner JB.

Antigenotoxic spinasterol from Cucurbita maxima flowers.

Mutat Res. 1996; 360: 89-93.

http://dx.doi.org/10.1016/0165-1161(95)00071-2

[129] Azevedo-Meleiro CH, Rodriguez-Amaya DB.

Qualitative and quantitative differences in carotenoid composition among Cucurbita moschata, Cucurbita maxima, and Cucurbita pepo.

J Agric Food Chem. 2007; 55: 4027-4033.

http://dx.doi.org/10.1021/jf063413d 
[130] Stevenson DG, Eller FJ, Wang L, Jane JL, Wang T, Inglett GE.

Oil and tocopherol content and composition of pumpkin seed oil in 12 cultivars.

J Agric Food Chem. 2007; 55: 4005-4013.

http://dx.doi.org/10.1021/jf0706979

[131] Rezig L, Chouaibi M, Msaada K, Hamdi S.

Chemical composition and profile characterisation of pumpkin (Cucurbita maxima) seed oil.

Ind Crop Prod 2012; 37: 82-87.

http://dx.doi.org/10.1016/j.indcrop.2011.12.004

[132] Srbinoska M, Hrabovski N, Rafajlovska V, Sinadinovic-Fiser S.

Characterisatin of the seed and seed extracts of the pumpkins Cucurbita maxima D. and Cucurbita pepo L. from Macedonia.

Macedon J Chem Chemical Eng. 2012; 31: 65-78.

[133] Andjelkovic M, Van Camp J, Trawka A, Verhe R.

Phenolic compounds and some quality parameters of pumpkin seed oil.

Eur J Lipid Sci Tech. 2010; 112: 208-217.

http://dx.doi.org/10.1002/ejlt.200900021

[134] Nara K, Yamaguchi A, Maeda N, Koga H.

Antioxidative activity of water soluble polysaccharide in pumpkin fruits (Cucurbita maxima Duchesne).

Biosci Biotechnol Biochem. 2009; 73: 1416-1418.

http://dx.doi.org/10.1271/bbb.80529

[135] Bowman T, Barringer S.

Analysis of factors affecting volatile compound formation in roasted pumpkin seeds with selected Ion Flow Tube-Mass Spectrometry (SIFT-MS) and sensory analysis.

J Food Sci. 2012; 77: C51-C60.

http://dx.doi.org/10.1111/j.1750-3841.2011.02465.x

[136] de Cerqueira PM, Freitas MCJ, Pumar M, Santangelo SB.

The pumpkin (Cucurbita maxima, L.) seed flour effect on the rat glucose and lipid metabolism.

Braz J Nutr. 2008; 21: 129-136.

[137] Rózycki J, Kupryszewski G, Rolka K, Ragnarsson U, Zbyryt T, Krokoszyńska I, Wilusz T. New active analogues of Cucurbita maxima trypsin inhibitor III (CMTI-III) modified in the non-contact region.

Biol Chem Hoppe Seyler. 1994; 375: 21-23.

http://dx.doi.org/10.1515/bchm3.1994.375.1.21

[138] Shan J, Baguinon M, Zheng L, Krishnamoorthi R.

Expression, refolding, and activation of the catalytic domain of human blood coagulation factor XII.

Protein Expr Purif. 2003; 27: 143-149.

http://dx.doi.org/10.1016/S1046-5928(02)00608-3

[139] Mullai K, Jebanesan A.

Larvicidal, ovicidal and repellent activities of the leaf extract of two cucurbitacious plants against filarial vector Culex quinquefasciatus (Say) (Diptera: Culicidae).

Trop Biomed. 2007; 24: 1-6.

http://www.ncbi.nlm.nih.gov/pubmed/17568371

[140] Cairnes DA, Ekundayo O, Kingston DG.

Plant anticancer agents. X. Lignans from Juniperus phoenicea.

J Nat Prod. 1980; 43: 495-497.

http://dx.doi.org/10.1021/np50010a010

[141] Comte G, Chulia AJ, Vercauteren J, Allais DP.

Phenylpropane glycosides from Juniperus phoenicea.

Planta Med. 1996; 62: 88-89.

http://dx.doi.org/10.1055/s-2006-957817 
[142] Rezzi S, Cavaleiro C, Bighelli A, Salgueiro L, da Cunha AP, Casanova J.

Intraspecific chemical variability of the leaf essential oil of Juniperus phoenicea subsp. turbinata from Corsica.

Biochem Syst Ecol. 2001; 29: 179-188.

http://dx.doi.org/10.1016/S0305-1978(00)00044-2

[143] Angioni A, Barra A, Russo MT, Coroneo V, Dessi S, Cabras P.

Chemical composition of the essential oils of Juniperus from ripe and unripe berries and leaves and their antimicrobial activity.

J Agric Food Chem. 2003; 51: 3073-3078.

http://dx.doi.org/10.1021/jf026203j

[144] Cosentino S, Barra A, Pisano B, Cabizza M, Pirisi FM, Palmas F.

Composition and antimicrobial properties of Sardinian Juniperus essential oils against foodborne

pathogens and spoilage microorganisms.

J Food Prot. 2003; 66: 1288-1291.

http://www.ncbi.nlm.nih.gov/pubmed/12870766

[145] Barrero AF, Herrador MM, Arteaga R, del Moral JFQ, Sanchez-Fernandez E, Akssira M, Aitigri M, Mellouki F, Akkad S.

Chemical composition of the essential oil from the leaves of Juniperus phoenicea L. from North Africa.

J Ess Oil. 2006; 18: 168-169

http://dx.doi.org/10.1080/10412905.2006.9699057

[146] Dob T, Dahmane D, Chelghoum C.

Chemical composition of the essential oil of Juniperus phoenicea L. from Algeria.

J Ess Oil. 2008; 20: 15-20.

http://dx.doi.org/10.1080/10412905.2008.9699410

[147] Yvon Y, Raoelison EG, Razafindrazaka R, Randriantsoa A, Romdhane M, Chabir N, Mkaddem MG, Bouajila J.

Relationship between chemical composition or antioxidant activity and antihypertensive activity for six essential oils.

J Food Sci. 2012; 77: H184-H191.

http://dx.doi.org/10.1111/j.1750-3841.2012.02812.x

[148] Tavares L, McDougall GJ, Fortalezas S, Stewart D, Ferreira RB, Santos CN.

The neuroprotective potential of phenolic-enriched fractions from four Juniperus species found in

Portugal.

Food Chem. 2012; 135: 562-570.

http://dx.doi.org/10.1016/j.foodchem.2012.05.023

[149] Achak N, Romane A, Alifriqui M, Adams RP.

Chemical studies of leaf essential oils of three species of Juniperus from Tensift Al Haouz-Marrakech Region (Morocco).

J Ess Oil Res. 2009; 21: 337-341.

http://dx.doi.org/10.1080/10412905.2009.9700185

[150] Derwich E, Benziane Z, Boukir A.

Chemical composition of leaf essential oil of Juniperus phoenicea and evaluation of its antibacterial activity.

Int J Agric Biol. 2010; 12: 199-204.

[151] Mazari K, Bendimerad N, Bekhechi C, Fernandez X.

Chemical composition and antimicrobial activity of essential oils isolated from Algerian Juniperus

phoenicea L. and Cupressus sempervirens L.

J Med Plant Res. 2010; 4: 959-964.

[152] Ennajar M, Afloulous S, Romdhane M, Ibrahim H, Cazaux S, Abderraba M, Raies A, Bouajila J. Influence of the process, season, and origin on volatile composition and antioxidant activity of Juniperus phoenicea L. leaves essential oils.

J Food Sci. 2011; 76: C224-C230.

http://dx.doi.org/10.1111/j.1750-3841.2010.01995.x 
[153] Fouad B, Abderrahmane R, Youssef A, Rajae H, El Fels MA.

Chemical composition and antibacterial activity of the essential oil of Moroccan Juniperus phoenicea.

Nat Prod Commun. 2011; 6: 1515-1518.

http://www.ncbi.nlm.nih.gov/pubmed/22164797

[154] Ait-Ouazzou A, Lorán S, Arakrak A, Laglaoui A, Rota C, Herrera A, Pagán R, Conchello P. Evaluation of the chemical composition and antimicrobial activity of Mentha pulegium, Juniperus phoenicea, and Cyperus longus essential oils from Morocco.

Food Res Int. 2012; 45: 313-319.

http://dx.doi.org/10.1016/j.foodres.2011.09.004

[155] Vourlioti-Arapi F, Michaelakis A, Evergetis E, Koliopoulos G, Haroutounian SA.

Essential oils of indigenous in Greece six Juniperus taxa Chemical composition and larvicidal activity against the West Nile virus vector Culex pipiens.

Parasitol Res. 2012; 110: 1829-1839.

http://dx.doi.org/10.1007/s00436-011-2706-8

[156] Barrero AF, Quilez del Moral JF, Herrador MM, Akssira M, Bennamara A, Akkad S, Aitigri M. Oxygenated diterpenes and other constituents from Moroccan Juniperus phoenicea and Juniperus thurifera var. africana.

Phytochemistry. 2004; 65: 2507-2515.

http://dx.doi.org/10.1016/j.phytochem.2004.07.021

[157] el-Sawi SA, Motawae HM, Ali AM.

Chemical composition, cytotoxic activity and antimicrobial activity of essential oils of leaves and berries of Juniperus phoenicea L. grown in Egypt.

Afr J Tradit Complement Altern Med. 2007; 4: 417-426.

http://www.ncbi.nlm.nih.gov/pubmed/20161910

[158] Medini H, Elaissi A, Farhat F, Khouja ML, Chemli R, Harzallah-Skhiri F.

Seasonal and geographical influences on the chemical composition of Juniperus phoenicea L. essential oil leaves from the Northern Tunisia.

Chem Biodivers. 2009; 6: 1378-1387.

http://dx.doi.org/10.1002/cbdv.200800202

[159] Ennajar M, Bouajila J, Lebrihi A, Mathieu F, Abderraba M, Raies A, Romdhane M.

Chemical composition and antimicrobial and antioxidant activities of essential oils and various extracts of Juniperus phoenicea L. (Cupressacees).

J Food Sci. 2009; 74: M364-M371.

http://dx.doi.org/10.1111/j.1750-3841.2009.01277.x

[160] Ennajar M, Bouajila J, Lebrihi A, Mathieu F, Savagnac A, Abderraba M, Raies A, Romdhane M. The influence of organ, season and drying method on chemical composition and antioxidant and antimicrobial activities of Juniperus phoenicea L. essential oils.

J Sci Food Agric. 2010; 90: 462-470.

http://dx.doi.org/10.1002/jsfa.3840

[161] Nasri N, Tlili N, Elfalleh W, Cherif E, Ferchichi A, Khaldi A, Triki S.

Chemical compounds from Phoenician juniper berries (Juniperus phoenicea).

Nat Prod Res. 2011; 25: 1733-1742.

http://dx.doi.org/10.1080/14786419.2010.523827

[162] Medini H, Elaissi A, Larbi Khouja M, Piras A, Porcedda S, Falconieri D, Marongiu B, Chemli R. Chemical composition and antioxidant activity of the essentail oil of Juniperus phoenicea L.

Nat Prod Res. 2011; 25: 1695-1706.

http://dx.doi.org/10.1080/14786419.2010.535168

[163] Mansouri N, Satrani B, Ghanmi M, El Ghadraoui L, Aafi A.

Chemical and biological study of essential oils of Moroccan Juniperus phoenicea ssp lycia and Juniperus phoenicea ssp turbinata.

Biotech Agron Soc Env. 2011; 15: 415-424. 
[164] Hayouni E, Abedrabba M, Bouix M, Hamdi M.

The effects of solvents and extraction method on the phenolic contents and biological activities in vitro of Tunisian Quercus coccifera L. and Juniperus phoenicea L. fruit extracts.

Food Chem 2007; 105: 1126-1134.

http://dx.doi.org/10.1016/j.foodchem.2007.02.010

[165] Cosentino S, Barra A, Pisano B, Cabizza M, Pirisi FM, Palmas F.

Composition and antimicrobial properties of Sardinian Juniperus essential oils against foodborne pathogens and spoilage microorganisms.

J Food Prot. 2003; 66: 1288-1291.

http://www.ncbi.nlm.nih.gov/pubmed/12870766

[166] Ozturk M, Tumen I, Ugur A, Aydogmus-Ozturk F, Topcu G.

Evaluation of fruit extracts of six Turkish Juniperus species for their antioxidant, anticholinesterase and antimicrobial activities.

J Food Agric Sci. 2011; 91: 867-876.

http://dx.doi.org/10.1002/jsfa.4258

[167] Samoylenko V, Dunbar DC, Gafur MA, Khan SI, Ross SA, Mossa JS, El-Feraly FS, Tekwani BL, Bosselaers J, Muhammad I.

Antiparasitic, nematicidal and antifouling constituents from Juniperus berries.

Phytother Res. 2008; 22: 1570-1576.

http://dx.doi.org/10.1002/ptr.2460

[168] Garboui SS, Borg-Karlson AK, Palsson K.

Tick repellent properties of three Libyan plants.

J Med Entomol. 2009; 46: 1415-1419.

http://dx.doi.org/10.1603/033.046.0623

[169] Ali SA, Rizk MZ, Ibrahim NA, Abdallah MS, Sharara HM, Moutafa MM.

Protective role of Juniperus phoenicea and Cupressus sempervirens against $\mathrm{CCl}_{4}$.

World J Gastrointest Pharmacol Ther. 2010; 1: 123-131.

http://dx.doi.org/10.4292/wjgpt.v1.i6.123

[170] Abdel-Kader MS, Alqasoumi SI.

Efficacy and safety of Juniperus phoenicea extracts useed as as remedy for liver in Saudi Arabia.

Planta Med. 2008; 74: PA171.

http://dx.doi.org/10.1055/s-0028-1084169

[171] Tumen I, Suntar I, Keles H, Kupeil Akkol E.

A therapeutic approach for wound healing by using essential oils of Cupressus and Juniperus species growing in Turkey.

Evid Based Complement Alternat Med. 2012; 2012: 728281.

http://dx.doi.org/10.1155/2012/728281

[172] Ito H, Yamaguchi K, Kim TH, Khennouf S, Gharzouli K, Yoshida T.

Dimeric and trimeric hydrolyzable tannins from Quercus coccifera and Quercus suber.

J Nat Prod. 2002; 65: 339-345.

http://dx.doi.org/10.1021/np010465i

[173] Khennouf S, Benabdallah H, Gharzouli K, Amira S, Ito H, Kim TH, Yoshida T, Gharzouli A.

Effect of tannins from Quercus suber and Quercus coccifera leaves on ethanol-induced gastric lesions in mice.

J Agric Food Chem. 2003; 51: 1469-1473.

http://dx.doi.org/10.1021/jf020808y

[174] Ormeno E, Fernandez C, Mevy JP.

Plant coexistence alters terpene emission and content of Mediterranean species.

Phytochemistry. 2007; 68: 840-852.

http://dx.doi.org/10.1016/j.phytochem.2006.11.033 
[175] Alkofahi A, Atta AH.

Pharmacological screening of the anti-ulcerogenic effects of some Jordanian medicinal plants in rats.

J Ethnopharmacol. 1999; 67: 341-345.

http://dx.doi.org/10.1016/S0378-8741(98)00126-3

[176] Manolaraki F, Sotiraki S, Stefanakis A, Skampardonis V, Volanis M, Hoste H.

Anthelmintic activity of some Mediterranean browse plants against parasitic nematodes.

Parasitology. 2010; 137: 685-696.

http://dx.doi.org/10.1017/S0031182009991399

[177] Peterson A, Machmudah S, Roy BC, Goto M, Sasaki M, Hirose T.

Extraction of essential oil from geranium (Pelargonium graveolens) with supercritical carbon dioxide.

J Chem Tech Biotech. 2006; 81: 167-172.

http://dx.doi.org/10.1002/jctb.1375

[178] Rao BRR.

Chemical composition and uses of Indian rose-scented geranium (Pelargonium species) essential oil A review.

J Ess Oil-Bear Plant. 2009; 12: 381-394.

http://dx.doi.org/10.1080/0972060X.2009.10643735

[179] Seo SM, Kim J, Lee SG, Shin CH, Shin SC, Park IK.

Fumigant antitermitic activity of plant essential oils and components from Ajowan (Trachyspermum ammi), Allspice (Pimenta dioica), caraway (Carum carvi), dill (Anethum graveolens), Geranium (Pelargonium graveolens), and Litsea (Litsea cubeba) oils against Japanese termite (Reticulitermes speratus Kolbe).

J Agric Food Chem. 2009; 57: 6596-6602.

http://dx.doi.org/10.1021/j9015416

[180] Bayoub K, Baibai T, Mountassif D, Retmane A, Soukri A.

Antibacterial activities of the crude ethanol extracts of medicinal plants against Listeria monocytogenes and some other pathogenic strains.

Afr J Biotech. 2010; 9: 4251-4258.

[181] Misra A, Srivastava NK.

Value addition of essential monoterpene oil(s) in Geranium (Pelargonium graveolens) on leaf positions for commercial exploitation.

Afr J Agric Res. 2010; 5: 2077-2079.

[182] Cavar SE, Maksimovic M.

Antioxidant activity of essential oil and aqueous extract of Pelargonium graveolens L'Her.

Food Cont. 2012; 23: 263-267.

http://dx.doi.org/10.1016/j.foodcont.2011.07.031

[183] Pohlit AM, Lopes NP, Gama RA, Tadei WP, Neto VF.

Patent literature on mosquito repellent inventions which contain plant essential oils-a review.

Planta Med. 2011; 77: 598-617.

http://dx.doi.org/10.1055/s-0030-1270723

[184] Dorman HJ, Dean SG.

Antimicrobial agents from plants: antibacterial activity of plant volatile oil.

J Appl Microbiol. 2000; 88: 308-316.

http://dx.doi.org/10.1046/j.1365-2672.2000.00969.x

[185] Rosato A, Vitali C, De Laurentis N, Armenise D, Antonietta Milillo M.

Antibacterial effect of some essential oils administered alone or in combination with Norfloxacin.

Phytomedicine. 2007; 14: 727-732.

http://dx.doi.org/10.1016/j.phymed.2007.01.005 
[186] Jaenson TG, Carboui S, Palsson K.

Repellency of oils of lemon eucalyptus, geranium, and lavender and the mosquito repellent MyggA natural to Ixodes ricinus (Acari: Ixodidae) in the laboratory and field.

J Med Entomol. 2006; 43: 731-736.

http://dx.doi.org/10.1603/0022-2585(2006)43[731:ROOOLE]2.0.CO;2

[187] Zhuang SR, Chiu HF, Chen SL, Tsai JH, Lee MY, Lee HS, Shen YC, Yan YY, Shane GT, Wang CK. Effects of a Chinese medical herbs complex on cellular immunity and toxicity-related conditions of breast cancer patients.

Br J Nutr. 2012; 107: 712-718.

http://dx.doi.org/10.1017/S000711451100345X

[188] Bondi ML, Al-Hillo MRY, Lamara K, Ladjel S, Bruno M, Piozzi F, Simmonds MSJ.

Occurrence of the antifeedant 14,15-dihydroajugapitin in the aerial parts of Ajuga iva from Algeria.

Biochem Syst Eco. 2000; 28: 1023-1025.

http://dx.doi.org/10.1016/S0305-1978(00)00012-0

[189] Sabri NN, Asaad A, Khafagy SM.

Isolation of four ecdysones from Ajuga iva roots and a rapid semiquantitative method for ecdysone determination.

Planta Med. 1981; 42: 293-295.

http://dx.doi.org/10.1055/s-2007-971644

[190] Coll J.

New minor ecdysteroids from Ajuga iva (Labiatae) and complete H-1-NMR assignment of cyasteronee.

Afinidad. 2007; 64: 242-250

[191] Hamden K, Ayadi F, Jamoussi K, Masmoudi H, Elfeki A.

Therapeutic effect of phytoecdysteroids rich extract from Ajuga iva on alloxan induced diabetic rats liver, kidney and pancreas.

Biofactors. 2008; 33: 165-175.

http://dx.doi.org/10.1002/biof.5520330302

[192] Bouderbala S, Prost J, Lacaille-Dubois MA, Bouchenak M.

Iridoid extracts from Ajuga iva increase the antioxidant enzyme activities in red blood cells of rats fed a cholesterol-rich diet.

Nutr Res. 2010; 30: 358-365.

http://dx.doi.org/10.1016/j.nutres.2010.05.004

[193] Dinda B, Debnath S, Banik R.

Naturally occurring iridoids and secoiridoids. An updated review, Part 4.

Chem Pharm Bull. 2011; 59: 803-833.

http://dx.doi.org/10.1248/cpb.59.803

[194] El-Hilay J, Lyoussi B.

Hypoglycaemic effect of the lyophilized aqueous extract of Ajuga iva in normal and streptozocin diabetic rats.

J Ethnopharmacol. 2002; 80: 109-113.

http://dx.doi.org/10.1016/S0378-8741(01)00407-X

[195] El-Hilay J, Tahraoui A, Ismaili ZH, Lyoussi B.

Acute hypoglycaemic, hypocholesterolemic and hypotriglyceridemic effects of continuous intravenous infusion of a lyophilised aqueous extract of Ajuga iva L. Schreber whole plant in streptozotocininduced diabetic rats.

Pak J Pharm Sci. 2007; 20: 261-268.

http://www.ncbi.nlm.nih.gov/pubmed/17604246

[196] El-Hilaly J, Lyoussi B, Wibo M, Morel N.

Vasorelaxant effect of the aqueous extract of Ajuga iva in rat aorta.

J Ethnopharmacol. 2004; 93: 69-74.

http://dx.doi.org/10.1016/j.jep.2004.03.020 
[197] El-Hilay J, Tahraoui A, Ismaili ZH, Lyoussi B.

Hypolipidemic effects of acute and sub-chronic administration of an aqueous extract of Ajuga iva $\mathrm{L}$. whole plant in normal and diabetic rats.

J Ethnopharmacol. 2006; 105: 441-448.

http://dx.doi.org/10.1016/j.jep.2005.11.023

[198] Bouderbala S, Lamri-Senhadji M, Prost J, Lacaille-Dubois MA, Bouchenak M.

Changes in antioxidant defense status in hypercholesterolemic rats treated with Ajuga iva.

Phytomedicine. 2008; 15: 453-461.

http://dx.doi.org/10.1016/j.phymed.2007.10.001

[199] Taleb-Senouci D, Lacaille-Dubois MA, Bouchenak M.

Ajuga iva aqueous extract improves reverse cholesterol transport in streptozotocin-induced diabetic rat.

J Pharm Pharmacol. 2012; 64: 1188-1194.

http://dx.doi.org/10.1111/j.2042-7158.2012.01501.x

[200] Chenni A, Yahia DA, Boukortt FO, Prost J, Lacaille-Dubois MA, Bouchenak M.

Effect of aqueous extract of Ajuga iva supplementation on plasma lipid profile and tissue antioxidant status in rats fed a high-cholesterol diet.

J Ethnopharmacol. 2007; 109: 207-213.

http://dx.doi.org/10.1016/j.jep.2006.05.036

[201] Taleb-Senouci D, Ghomari H, Krouf D, Bouderbala S, Prost J, Lacaille-Dubois MA, Bouchenak M. Antioxidant effect of Ajuga iva aqueous extract in streptozotocin-induced diabetic rats.

Phytomedicine. 2009; 16: 623-631.

http://dx.doi.org/10.1016/j.phymed.2008.12.004

[202] Beghalia M, Ghalem S, Allalia H, Belouatek A, Marouf A.

Effects of Atriplex halimus and Ajuga iva L. Schreb on calcium oxalate Uurolithiasis risk in vitro.

Asian J Chem. 2009; 21: 1119-1125.

[203] Jbilou R, Amri H, Bouayad N, Ghailani N, Ennabili A, Sayah F. Insecticidal effects of extracts of seven plant species on larval development, alpha-amylase activity and offspring production of Tribolium castaneum (Herbst) (Insecta: Coleoptera: Tenebrionidae). Bioresour Technol. 2008; 99: 959-964. http://dx.doi.org/10.1016/j.biortech.2007.03.017

[204] Jbilou R, Ennabili A, Sayah F. Insecticidal activity of four medicinal plant extracts against Tribolium castaneum (Herbst) (Coleoptera: Tenebrionidae).

Afr J Biotech. 2006; 5: 936-940.

[205] Ahmad S, Ahmad I, Saleem M, Jabbar A, Nisar-Ur-Rehman, Saeed-Ul-Hassan S, Akhtar KS, Choudhary MI.

Secondary Metabolites from Alhagi maurorum.

J Chem Soc Pak. 2009; 31: 960-963.

[206] Ahmad S, Riaz N, Saleem M, Jabbar A, Nisar-Ur-Rehman, Ashraf M. Antioxidant flavonoids from Alhagi maurorum.

J Asian Nat Prod Res. 2010; 12: 138-143.

http://dx.doi.org/10.1080/10286020903451724

[207] Laghari AH, Ali Memon A, Memon S, Nelofar A, Khan KM, Yasmin A.

Determination of free phenolic acids and antioxidant capacity of methanolic extracts obtained from leaves and flowers of camel thorn (Alhagi maurorum).

Nat Prod Res. 2012; 26:173-176.

http://dx.doi.org/10.1080/14786419.2010.538846

[208] Shaker E, Mahmoud H, Mnaa S.

Anti-inflammatory and anti-ulcer activity of the extract from Alhagi maurorum (camelthorn).

Food Chem Toxicol. 2010; 48: 2785-2790.

http://dx.doi.org/10.1016/j.fct.2010.07.007 
[209] Laghari AH, Memon S, Nelofar A, Khan KM, Yasmin A, Syed, MN, Aman A.

A new flavanenol with urease-inhibition activity isolated from roots of manna plant camelthorn (Alhagi maurorum).

J Mol Struct. 2010; 965: 65-67.

http://dx.doi.org/10.1016/j.molstruc.2009.11.039

[210] Laghari AH, Memon S, Nelofar A, Khan KM.

Alhagi maurorum: A convenient source of lupeol. Ind Crop Prod. 2011; 34: 1141-1145.

http://dx.doi.org/10.1016/j.indcrop.2011.03.031

[211] Abu-Taleb AM, El-Deeb K, Al-Otibi FO.

Bioactivity of some plant extracts against Drechslera biseptata and Fusarium solani.

J Food Agric Env. 2011; 9: 769-774.

[212] Oskoueian A,Oskoueian E, Rudi H, Farida Z, Fatemeh S, Karimi E.

Antioxidant activity and bioactive compounds in Alhagi maurorum.

Clin Biochem. 2011; 44: S343-S344.

http://dx.doi.org/10.1016/j.clinbiochem.2011.08.856

[213] Awaad AS, El-Meligy RM, Qenawy SA, Atta AH, Soliman GA.

Anti-inflammatory, antinociceptive and antipyretic effects of some desert plants.

J Saudi Chem Soc. 2011; 15:367-373.

http://dx.doi.org/10.1016/j.jscs.2011.02.004

[214] Shaker E, Mahmoud H, Mnaa S.

Anti-inflammatory and anti-ulcer activity of the extract from Alhagi maurorum (camelthorn).

Food Chem Toxicol. 2010; 48: 2785-2790.

http://dx.doi.org/10.1016/j.fct.2010.07.007

[215] Awaad Amani AS, Maitland DJ, Soliman GA.

Antiulcerogenic activity of Alhagi maurorum.

Pharm Biol. 2006; 44: 292-296.

http://dx.doi.org/10.1080/13880200600714160

[216] Naseri MKG, Mard SA.

Gastroprotective effect of Alhagi maurorum on exprimental gastric ulcer in rats.

Pak J Med Sci. 2007; 23: 570-573.

[217] Atta AH, Abo EL-Sooud K.

The antinociceptive effect of some Egyptian medicinal plant extracts.

J Ethnopharmacol. 2004; 95: 235-238.

http://dx.doi.org/10.1016/j.jep.2004.07.006

[218] Atta AH, Mouneir SM.

Antidiarrhoeal activity of some Egyptian medicinal plant extracts.

J Ethnopharmacol. 2004; 92: 303-309.

http://dx.doi.org/10.1016/j.jep.2004.03.017

[219] Marashdah MS, Farraj Al.

Pharmacological activity of $2 \%$ aqueous acetic acid extract of Alhagi maurorum rootst.

J Saudi Chem Soc. 2010; 14: 247-250.

http://dx.doi.org/10.1016/j.jscs.2010.02.015

[220] Marashdah MS, Al-Hazimi HM.

Pharmacological activity of ethanolic extract of Alhagi maurorum roots.

Arab J Chem. 2010; 3: 39-42.

http://dx.doi.org/10.1016/j.arabjc.2009.12.007

[221] Ashraf M, Ahmad K, Ahmad I, Ahmad S, Arshad S, Shah SMA, Nasim FUH.

Acetylcholinesterase and NADH oxidase inhibitory activity of some medicinal plants.

J Med Plant Res. 2011; 5: 2086-2089. 
[222] Rahman SMA, Abd-Ellatif SA, Deraz SF, Khalil AA.

Antibacterial activity of some wild medicinal plants collected from western Mediterranean coast, Egypt: Natural alternatives for infectious disease treatment.

Afr J Biotech. 2011; 10: 10733-10743.

[223] Sadaqa EA, Bawazir AA, Qasem JR.

Allelopathic activity of some common weeds species in onion fields.

Allelopathy J. 2010; 26: 175-184.

[224] Allerdings E, Ralph J, Steinhart $\mathrm{H}$, Bunzel M.

Isolation and structural identification of complex feruloylated heteroxylan side-chains from maize bran.

Phytochemistry. 2006; 67: 1276-1286.

http://dx.doi.org/10.1016/j.phytochem.2006.04.018

[225] Suzuki R, Okada Y, Okuyama T.

A new flavone C-glycoside from the style of Zea mays L. with glycation inhibitory activity.

Chem Pharm Bull (Tokyo). 2003; 51: 1186-1188.

http://dx.doi.org/10.1248/cpb.51.1186

[226] Suzuki R, lijima M, Okada Y, Okuyama T.

Chemical constituents of the style of Zea mays L. with glycation inhibitory activity.

Chem Pharm Bull (Tokyo). 2007; 55: 153-155.

http://dx.doi.org/10.1248/cpb.55.153

[227] Ranilla LG, Apostolidis E, Genovese MI, Lajolo FM, Shetty K.

Evaluation of indigenous grains from the Peruvian Andean region for antidiabetes and

antihypertension potential using in vitro methods.

J Med Food. 2009; 12: 704-713.

http://dx.doi.org/10.1089/jmf.2008.0122

[228] Barros-Rios J, Malvar RA, Jung HJ, Santiago R.

Cell wall composition as a maize defense mechanism against corn borers.

Phytochemistry. 2011; 72: 365-371.

http://dx.doi.org/10.1016/j.phytochem.2011.01.004

[229] Li J, Lim SS, Lee JY, Kim JK, Kang SW, Kim JL, Kang YH.

Purple corn anthocyanins dampened high-glucose-induced mesangial fibrosis and inflammation:

possible renoprotective role in diabetic nephropathy.

J Nutr Biochem. 2012; 23: 320-331.

http://dx.doi.org/10.1016/j.jnutbio.2010.12.008

[230] Suzuki R, Okada Y, Okuyama T.

The favorable effect of style of Zea mays L. on streptozotocin induced diabetic nephropathy.

Biol Pharm Bull. 2005; 28: 919-920.

http://dx.doi.org/10.1248/bpb.28.919

[231] Miao MS, Zhang GL, Miao YY, Shi JJ, Liu HL.

Influence of Zea mays L. saponin (ZMLS) on ultrastructure of kidney and pancreas in diabetes rats induced by streptozocin.

Zhongguo Zhong Yao Za Zhi. 2008; 33: 1179-1183.

[232] Lee CH, Garcia HS, Parkin KL.

Bioactivities of kernel extracts of 18 strains of maize (Zea mays).

J Food Sci. 2010; 75: C667-C672.

http://dx.doi.org/10.1111/j.1750-3841.2010.01784.x

[233] Rau O, Wurglics M, Dingermann T, Abdel-Tawab M, Schubert-Zsilavecz M.

Screening of herbal extracts for activation of the human peroxisome proliferator-activated receptor. Pharmazie. 2006; 61: 952-956.

http://www.ncbi.nlm.nih.gov/pubmed/17152989 
[234] Li W, Wei CV, White PJ, Beta T.

High-amylose corn exhibits better antioxidant activity than typical and waxy genotypes.

J Agric Food Chem. 2007; 55: 291-298.

http://dx.doi.org/10.1021/jf0622432

[235] Meiouet F, El Kabbaj S, Daudon M.

In vitro study of the litholytic effects of herbal extracts on cystine urinary calculi.

Prog Urol. 2011; 21: 40-47.

http://dx.doi.org/10.1016/j.purol.2010.05.009

[236] Baytop T.

Therapy with Medicinal Plants in Turkey.

$2^{\text {nd }}$ Edition. (Nobel Tip Kitabevleri, Istanbul) pp. 319-320, 1999.

[237] Alaadin AM. Al-Khateeb EH, Jager AK.

Antibacterial activity of the Iraqi Rheum ribes root.

Pharm Biol. 2007; 45: 688-690.

http://dx.doi.org/10.1080/13880200701575049

[238] Ozcan MM, Dursun N, Arslan D.

Some nutritional properties of Prangos ferulacea (L.) Lindl and Rheum ribes L. stems growing wild in Turkey.

Int J Food Sci Nutr. 2007; 58: 162-167.

http://dx.doi.org/10.1080/09637480601154145

[239] Ozturk M, Aydozmus-Ozturk F, Duru ME, Topcu G.

Antioxidant activity of stem and root extracts of Rhubarb (Rheum ribes): An edible medicinal plant.

Food Chem. 2007; 103: 623-630.

http://dx.doi.org/10.1016/j.foodchem.2006.09.005

[240] Naqishbani AM, Josefsen K, Pedersen ME, Jager AK.

Hypoglycaemic activity of Iraqi Rheum ribes root extract.

Pharm Biol. 2009; 47: 380-383.

http://dx.doi.org/10.1080/13880200902748478

[241] Ozbek H, Ceylan E, Kara M, Ozgokce F, Koyuncu M.

Hypoglycaemic effect of Rheum ribes roots in alloxan induced diabetic and normal mice.

Scand J Lab Animal Sci. 2004; 31: 113-115.

[242] Hudson JB, Lee MK, Sener B, Erdemoglu N.

Antiviral activities in extracts of Turkish medicinal plants.

Pharm Biol. 2000; 38: 171-175.

http://dx.doi.org/10.1076/1388-0209(200007)3831-SFT171

[243] Bazzaz BSF, Khajehkaramadin M, Shokooheizadeh HR.

In vitro antibacterial activity of Rheum ribes extract obtained from various plant parts against clinical isolates of gram negative pathogens.

Iran J Pharm Res. 2005; 2: 87-91.

[244] Oktay M, Yildirim A, Bilaloglu V, Gulcin I.

Antioxidant activity of different parts of isgin (Rheum ribes L.).

Asian J Chem. 2007; 19: 3047-3055.

[245] Krishnaiah D, Sarbatly R, Nithyanandam R.

A review of the antioxidant potential of medicinal plant species.

Food Bioprod Proc. 2011; 89: 217-233.

http://dx.doi.org/10.1016/j.fbp.2010.04.008

[246] Sardari S, Shokrgozar MA, Ghavami G.

Cheminformatics based selection and cytotoxic effects of herbal extracts.

Toxicol In Vitro. 2009; 23: 1412-1421.

http://dx.doi.org/10.1016/j.tiv.2009.07.011 
[247] Ismaeil N, Hidayat $\mathrm{H}$.

The cytotoxic effect of the crude extracts of local rhubarb Rheum ribes L. in Kurdistan-Iraq on normal and cancer cell lines in vitro.

Basic Clin Pharm Toxicol. 2009; 105: 56-57.

[248] Sindhu RK, Kumar P, Kumar J, Kumar A, Arora S.

Investigations into the anti-ulcer activity of Rheum ribes Linn leaves extracts.

Int J Pharm Pharmaceut Sci. 2010; 2: 90-92.

[249] Sayyah M, Boostani H, Pakseresh S, Malayeri A.

Efficacy of hydroalcoholic extract of Rheum ribes L. in treatment of major depressive disorder.

J Med Plant Res. 2009; 3: 573-575.

[250] El-Din Hussein Mahran G, Glombitza KW, Mirhom YW, Hartmann R, Michel CG.

Novel saponins from Zizyphus spina-christi growing in Egypt.

Planta Med. 1996; 62: 163-165.

http://dx.doi.org/10.1055/s-2006-957842

[251] Abdel-Zaher AO, Salim SY, Assaf MH, Abdel-Hady RH.

Antidiabetic activity and toxicity of Zizyphus spina-christi leaves.

J Ethnopharmacol. 2005; 101: 129-138.

http://dx.doi.org/10.1016/j.jep.2005.04.007

[252] Pordel Shahri M, Shadizadeh SR, Jamialahmadi M.

A new type of surfactant for enhanced oil recovery.

Petrol Sci Tech. 2012; 30: 585-593.

http://dx.doi.org/10.1080/10916466.2010.489093

[253] Shahat AA, Pieters L, Apers S, Nazeif NM, Abdel-Azim NS, Berghe DV, Vlietinck AJ.

Chemical and biological investigations on Zizyphus spina-christi $\mathrm{L}$.

Phytother Res. 2001; 15: 593-597.

http://dx.doi.org/10.1002/ptr.883

[254] Pawlowska AM, Camangi F, Bader A, Braca A.

Flavonoids of Zizyphus jujuba L. and Zizyphus spina-christi (L.) Willd (Rhamnaceae) fruits.

Food Chem. 2009; 112: 858-862.

http://dx.doi.org/10.1016/j.foodchem.2008.06.053

[255] Ghannadi A, Tavakoli N, Mehri-Ardestani M.

Volatile constituents of the leaves of Ziziphus spinachristi (L.) Willd. from Bushehr, Iran.

J Ess Oil Res. 2003; 15: 191-192.

http://dx.doi.org/10.1080/10412905.2003.9712109

[256] Said A, Fawzy G, Abu Tabl ESA, Tzakou O.

Volatile constituents of Zizyphus jujuba aerial parts and Zizyphus spina-christii fruits from Egypt. J Ess Oil-Bear Plant. 2010; 13, 170-174.

http://dx.doi.org/10.1080/0972060X.2010.10643807

[257] Nazif NM.

Phytoconstituents of Zizyphus spina-christi L. fruits and their antimicrobial activity.

Food Chem. 2002; 76: 77-81.

http://dx.doi.org/10.1016/S0308-8146(01)00243-6

[258] Amoo IA, Atasie VN.

Nutritional and functional properties of Tamarindus indica pulp and Zizyphus spina-christi fruit and seed.

J Food Agric Env. 2012; 10: 16-19.

[259] Nesseem DI, Michel CG, Sleem AA, Al-Alfy TS.

Formulation and evaluation of antihyperglycemic leaf extracts of Zizyphus spina-christi (L.) Wild.

Pharmazie. 2009; 64: 104-109.

http://www.ncbi.nlm.nih.gov/pubmed/19320283 
[260] Michel CG, Nesseem DI, Ismail MF.

Anti-diabetic activity and stability study of the formulated leaf extract of Zizyphus spina-christi (L.) Willd with the influence of seasonal variation.

J Ethnopharmacol. 2011; 133: 53-62.

http://dx.doi.org/10.1016/j.jep.2010.09.001

[261] Avizeh R, Najafzadeh H, Pourmandi M, Mirzaee M.

Effect of glibenclamide and fruit extract of Zizyphus spina-christi on alloxan- induced diabetic dogs. Int J Appl Res Vet Med. 2010; 8: 109-113.

[262] Abdel-Wahhab MA, Omara EA, Abdel-Galil MM, Hassan NS, Nada SA, Saeed A, el-Sayed MM. Zizyphus spina-christi extract protects against aflatoxin B1-initiated hepatic carcinogenicity. Afr J Tradit Complement Altern Med. 2007; 4: 248-256.

[263] Abdel-Wahhab M, Abdel-Galil MM, Hassan AM, Hassan NS, Nada SA, Saeed A. Zizyphus spina-christi extract protects against aflatoxin B-1-initiated hepatic carcinogenicity. Toxicol Lett. 2005; 158: S68-S68.

[264] Amin A, Mahmoud-Ghoneim D.

Zizyphus spina-christi protects against carbon tetrachloride-induced liver fibrosis in rats.

Food Chem Toxicol. 2009; 47: 2111-2119.

http://dx.doi.org/10.1016/j.fct.2009.05.038

[265] Godini A, Kazem M, Naseri G, Badavi M.

The effect of Ziziphus spina-christi leaf extract on isolated rat aorta.

J Pak Med Assoc. 2009; 53: 537-539.

http://www.ncbi.nlm.nih.gov/pubmed/19757700

[266] Hadizadeh I, Peivastegan B, Kolahi M.

Antifungal activity of nettle (Urtica dioica L.), colocynth (Citrullus colocynthis L. Schrad), oleander (Nerium oleander L.) and konar (Ziziphus spina-christi L.) extracts on plants pathogenic fungi. Pak J Biol Sci. 2009; 12: 58-63.

http://dx.doi.org/10.3923/pjbs.2009.58.63

[267] Adzu B, Amos S, Wambebe C, Gamaniel K.

Antinociceptive activity of Zizyphus spina-christi root bark extract.

Fitoterapia. 2001; 72: 344-350.

http://dx.doi.org/10.1016/S0367-326X(00)00289-6

[268] Adzu B, Haruna AK.

Studies on the use of Zizyphus spina-christi against pain in rats and mice.

Afr J Biotech. 2007; 6: 1317-1324.

[269] Adzu B, Amos S, Amizan MB, Gamaniel K.

Evaluation of the antidiarrhoeal effects of Zizyphus spina-christi stem bark in rats.

Acta Trop. 2003; 87: 245-250.

http://dx.doi.org/10.1016/S0001-706X(03)00114-1

[270] Adzu B, Amos S, Dzarma S, Wambebe C, Gamaniel K.

Effect of Zizyphus spina-christi Willd aqueous extract on the central nervous system in mice.

J Ethnopharmacol. 2002; 79: 13-16.

http://dx.doi.org/10.1016/S0378-8741(01)00348-8

[271] Kiselova Y, Ivanova D, Chervenkov T, Gerova D, Galunska B, Yankova T.

Correlation between the in vitro antioxidant activity and polyphenol content of aqueous extracts from Bulgarian herbs.

Phytother Res. 2006; 20: 961-965.

http://dx.doi.org/10.1002/ptr.1985

[272] Borodin YI, Selyatitskaya VG, Obukhova LA, Pal'chikova NA, Odintsov SV, Kukushkina TA.

Effects of polyphenol compounds from Alchemilla vulgaris on morphofunctional state of thyroid gland in rats exposed to low temperature.

Bull Exp Biol Med. 1999; 127: 637-639.

http://dx.doi.org/10.1007/BF02433301 
[273] Oktyabrsky O, Vysochina G, Muzyka N, Samoilova Z, Kukushkina T, Smirnova G. Assessment of anti-oxidant activity of plant extracts using microbial test systems.

J Appl Micr. 2009; 106: 1175-1183.

http://dx.doi.org/10.1111/j.1365-2672.2008.04083.x

[274] D'Agostino M, Dini I, Ramundo E, Senatore F.

Flavonoid glycosides of Alchemilla vulgaris $\mathrm{L}$.

Phyther Res. 1998; 12 (Suppl 1): S162-S163.

http://dx.doi.org/10.1002/(SICl)1099-1573(1998)12:1+3.0.CO;2-P

[275] Condrat D, Crisan F, Szabo MR, Chambree DR, Lupea AX.

Flavonoids in Angiospermatophyta and Spermatophyta species and their antioxidant activity.

Revista de Chimie. 2009; 60: 1129-1134.

[276] Smolyakova IM, Andreeva VY, Kalinkina GI, Avdeenko SN, Shchetinin PP.

Development of extraction techniques and standardization methods for a common lady's mantle

(Alchemilla vulgaris) extract.

Pharm Chem J. 2012; 45: 675-678.

http://dx.doi.org/10.1007/s11094-012-0702-7

[277] Djipa CD, Delmee M, Quetin-Leclercq J.

Antimicrobial activity of bark extracts of Syzygium jambos (L.) Alston (Myrtaceae).

J Ethnopharmacol. 2000; 71: 307-313.

http://dx.doi.org/10.1016/S0378-8741(99)00186-5

[278] Condrat D, Mosoarca C, Zamfir AD, Crisan F, Szabo MR, Lupea AX.

Qualitative and quantitative analysis of gallic acid in Alchemilla vulgaris, Allium ursinum, Acorus calamus and Solidago virga-aurea by chip-electrospray ionization mass spectrometry and high performance liquid chromatography.

Centr Eur J Chem. 2010; 8: 530-535.

http://dx.doi.org/10.2478/s11532-010-0012-4

[279] Said O, Saad B, Fulder S, Khalil K, Kassis E.

Weight loss in animals and humans treated with 'Weighlevel', a combination of four medicinal plants used in traditional Arabic and Islamic medicine.

Evid Based Complement Alternat Med. 2011; 24: 1-6.

http://dx.doi.org/10.1155/2011/207034

[280] Swanston-Flat SK, Day C, Bailey CJ, Flatt PR.

Traditional plant treatments for diabetes. Studies in normal and streptozotocin diabetic mice.

Diabetologia. 1990; 33: 462-464.

http://dx.doi.org/10.1007/BF00405106

[281] Shrivastava R, John GW.

Treatment of aphthous stomatitis with topical Achemilla vulgaris in glycerine.

Clin Drug Investig. 2006; 26: 567-573.

http://dx.doi.org/10.2165/00044011-200626100-00003

[282] Shrivastava R, Cucuat N, John GW.

Effects of Alchemilla vulgaris and glycerine on epithelial and myofibroblast cell growth and cutaneous lesion healing in rats.

Phytother Res. 2007; 21: 369-373.

http://dx.doi.org/10.1002/ptr.2060

[283] Condrat D, Szabo MR, Radu D, Lupea AX.

Plant spices from the Angiospermatophyta and Spermatophyta genus with antiradical and antimicrobial activity.

Oxid Commun. 2009; 32: 924-929.

[284] Keskin D, Oskay D, Oskay M.

Antimicrobial activity of selected plant species marketed in the West Anatolia.

Int J Agric Biol. 2010; 12: 916-920. 
[285] Sufka KJ, Roach JT, Chambliss WG, Broom SL, Feltenstein MW, Wyandt CM, Zeng L. Anxiolytic properties of botanical extracts in the chick social separation-stress procedure.

Psychopharmacol. 2001; 153: 219-224.

http://dx.doi.org/10.1007/s002130000571

[286] Reher G, Reznicek G, Baumann A.

Triterpenoids from Sarcopoterium spinosum and Sanguisorba minor.

Planta Med. 1991; 57: 506.

http://dx.doi.org/10.1055/s-2006-960189

[287] Sarikaya BB, Kayalar H.

Quantitative determination of a-tocopherol and quality control studies in Sarcopoterium spinosum $\mathrm{L}$.

Marmara Pharm J. 2011; 15: 2-10

[288] Reher G.

Proanthocyanidins from Poterium spinosum (Rosaceae).

Pharm Weekbl Sci. 1987; 9: 243-243.

[289] Bachrach ZY.

Ethnobotanical studies of Sarcopoterium spinosum in Israel.

Israel J Plant Sci. 2007; 55: 111-114.

http://dx.doi.org/10.1560/IJPS.55.1.111

[290] Schlutz GO, Venulet J.

[Poterium spinosum and its influence on the blood sugar level in rabbits].

Experientia. 1964; 15: 78-79.

http://www.ncbi.nlm.nih.gov/pubmed/5852158

[291] Mishkinsky J, Menczel E, Sulman FG.

Hypoglycaemic effect of Poterium spinosum L. (Rosaceae).

Arch Int Pharmacodyn Ther. 1966; 161: 306-313.

http://www.ncbi.nlm.nih.gov/pubmed/5926873

[292] Shani J, Joseph B, Sulman FG.

Fluctuations in the hypoglycaemic effect of Poterium spinosum L. (Rosaceae).

Arch Int Pharmacodyn Ther. 1970; 185: 344-349.

http://www.ncbi.nlm.nih.gov/pubmed/5473794

[293] Rosenzweig T, Abitbol G, Taler D.

Evaluating the anti-diabetic effects of Sareopoterium spinosum extracts in vitro.

Israel J Plant Sci. 2007; 55: 103-109.

http://dx.doi.org/10.1560/IJPS.55.1.103

[294] Smirin P, Taler D, Abitbol G, Brutman-Barazani T, Kerem Z, Sampson SR, Rosenzweig T.

Sarcopoterium spinosum extract as an antidiabetic agent: in vitro and in vivo study.

J Ethnopharmacol. 2010; 129: 10-17.

http://dx.doi.org/10.1016/j.jep.2010.02.021

[295] Auclair MC, Lemeignan M, Rodallec A.

Action potential changes induced by a polyflavane on normal or hypoxic guinea pig myocardial strips. C R Acad Sci Hebd Seances Acad Sci D. 1976; 283: 695-698.

[296] Durodola J.

Tumour inhibitory effects of crude extracts from Poterium spinosum.

Planta Med. 1975; 27: 231-234.

http://dx.doi.org/10.1055/s-0028-1097791

[297] Shahverdi AR, Saadat F, Khorramizadeh MR, Iranshahi M, Khoshayand MR.

Two matrix metalloproteinases inhibitors from Ferula persica var. persica.

Phytomedicine. 2006; 13: 712-717.

http://dx.doi.org/10.1016/j.phymed.2006.01.003 
[298] Iranshahi M, Amin GR, Jalalizadeh H, Shafiee A.

New germacrane derivative from Ferula persica.

Pharm Biol. 2003; 41: 431-433.

http://dx.doi.org/10.1076/phbi.41.6.431.17834

[299] Iranshahi M, Shahverdi AR, Mirjani R, Amin G, Shafiee A.

Umbelliprenin from Ferula persica roots inhibits the red pigment production in Serratia marcescens.

Z Naturforsch C. 2004; 59: 506-508.

http://www.ncbi.nlm.nih.gov/pubmed/15813369

[300] Mirjani R, Shahverdi AR, Iranshahi M, Amin G, Shafiee A.

Identification of antifungal compounds from Ferula persica var. persica.

Pharm Biol. 2005; 43: 293-295.

http://dx.doi.org/10.1080/13880200590951658

[301] Iranshahi M, Noroozi S, Behravan J, Karimi G, Schneider B.

Persicasulfide $C$, a new sulphur-containing derivative from Ferula persica.

Nat Prod. Res. 2009; 23: 1584-1588.

http://dx.doi.org/10.1080/14786410802393571

[302] Iranshahi M, Askari M, Sahebkar A, Hadjipavlou-Litina D.

Evaluation of antioxidant, anti-inflammatory and lipoxygenase inhibitory activities of the prenylated coumarin umbelliprenin.

Daru. 2009; 17: 99-103.

[303] Iranshahi M, Sahebkar A, Takasaki M, Konoshima T, Tokuda H.

Cancer chemopreventive activity of the prenylated coumarin, umbelliprenin, in vivo.

Eur J Cancer Prev. 2009; 18: 412-415.

http://dx.doi.org/10.1097/CEJ.0b013e32832c389e

[304] Iranshahi M, Amin G, Shafie A.

A new coumarin from Ferula persica.

Pharm Biol. 2004; 42: 440-442.

http://dx.doi.org/10.1080/13880200490886102

[305] Hanafi-Bojd MY, Iranshahi M, Mosaffa F, Tehrani SO, Kalalinia F, Behravan J.

Farnesiferol A from Ferula persica and galbanic acid from Ferula szowitsiana inhibit P-glycoproteinmediated rhodamine efflux in breast cancer cell lines.

Planta Med. 2011; 77: 1590-1593.

http://dx.doi.org/10.1055/s-0030-1270987

[306] Iranshahi M, Mojarab M, Sadeghian H, Hanafi-Bojd MY, Schneider B.

Polar secondary metabolites from Ferula persica roots.

Phytochemistry. 2008; 69: 473-478.

http://dx.doi.org/10.1016/j.phytochem.2007.08.001

[307] Javidnia K, Miri R, Kamalinejad M, Edraki N.

Chemical composition of Ferula persica Wild. essential oil from Iran.

Flav Frag J. 2005; 20: 605-606.

http://dx.doi.org/10.1002/ffj.1496

[308] Iranshahi M, Amin G, Sourmaghi MS, Shafiee A, Hadjiakhoondi A.

Sulphur-containing compounds in the essential oil of the root of Ferula persica Willd. var. Persica.

Flav Frag J. 2006; 21: 260-261.

http://dx.doi.org/10.1002/ffj.1574

[309] Asili J, Sahebkar A, Bazzaz BSF, Sharifi S, Iranshahi M.

Identification of essential oil components of Ferula badrakema fruits by GC-MS and C-13-NMR methods and evaluation of its antimicrobial activity.

J Ess Oil-Bear Plants.2009; 12: 7-15.

http://dx.doi.org/10.1080/0972060X.2009.10643685 
[310] Sahebkar A, Iranshahi M.

Volatile constituents of the genus Ferula (Apiaceae): A review.

J Ess Oil-Bear Plants.2011; 14: 504-531.

http://dx.doi.org/10.1080/0972060X.2011.10643969

[311] Noroozi S, Mosaffa F, Soltani F, Iranshahi M, Karimi G, Malekaneh M, Haghighi F, Behravan J. Antigenotoxic effects of the disulfide compound persicasulfide A (PSA) on rat lymphocytes exposed to oxidative stress.

Planta Med. 2009; 75: 32-36.

http://dx.doi.org/10.1055/s-0028-1088360

[312] Bagheri SM, Sahebkar A, Gohari AR, Saeidnia S, Malmir M, Iranshahi M.

Evaluation of cytotoxicity and anticonvulsant activity of some Iranian medicinal Ferula species.

Pharm Biol. 2010; 48: 242-246.

http://dx.doi.org/10.3109/13880200903081796

[313] Ziai SA, Gholami O, Iranshahi M, Zamani AH, Jeddi-Tehrani M. Umbelliprenin induces apoptosis in CLL cell lines.

Iran J Pharm Res. 2012; 11: 653-659.

[314] Pinelli P, Leri F, Vignolini P, Bacci L, Baronti S, Romani A.

Extraction and HPLC analysis of phenolic compounds in leaves, stalks, and textile fibers of Urtica dioica.

J Agric Food Chem. 2008; 56: 9127-9132.

http://dx.doi.org/10.1021/jf801552d

[315] Moldovan L, Gaspar A, Toma L, Craciunescu O, Saviuc C.

Comparison of polyphenolic content and antioxidant capacity of five Romanian traditional medicinal plants.

Revista di Chimie. 2011; 62: 299-303.

[316] Otles S, Yalcin B.

Phenolic compounds analysis of root, stalk, and leaves of nettle.

ScientificWorldJournal. 2012; 2012: 564367.

http://dx.doi.org/10.1100/2012/564367

[317] Akbay P, Basaran AA, Undeger U, Basaran N.

In vitro immunomodulatory activity of flavonoid glycosides from Urtica dioica $\mathrm{L}$.

Phytotherapy Res. 2003; 17: 34-37.

http://dx.doi.org/10.1002/ptr.1068

[318] Basaran AA, Akbay P, Undeger U, Basaran N.

In vitro immunomodulatory and mutagenic activity of the flavonoid glycosides from Urtica dioica $\mathrm{L}$.

Toxicology. 2001; 164: S171-S172.

[319] Ozcan C, Dilgin Y, Yaman M.

Determination of quercetin in medicinal plants such as rose hip (Rosa canina), nettle (Urtica dioica), terebinth (Terebinthina chica) and purslane (Portulace oleracea) using HPLC-MS method.

Asian J Chem. 2012; 24: 3396-3400.

[320] Ilies T, Radulescu V.

Chemical composition of the essential oil of Urtica dioica Ilies, DC.

Chem Nat Comp. 2012; 48: 506-507.

http://dx.doi.org/10.1007/s10600-012-0291-4

[321] Gül S, Demirci B, Baser KHC, Akpulat HA, Aksu P.

Chemical composition and in vitro cytotoxic, genotoxic effects of essential oil from Urtica dioica $\mathrm{L}$.

Bull Env Contamin Toxicol. 2012; 88: 666-671.

http://dx.doi.org/10.1007/s00128-012-0535-9

[322] Kraus R, Spiteller G.

[Lignan glucosides from roots of Urtica dioica].

Liebigs Ann Chem. 1990; 1205-1213

http://dx.doi.org/10.1002/jlac.1990199001218 
[323] Rohricht C.

Yield and constituents of greater nettle strains (Urtica dioica L.)

Z Arznei Gewürzpflanzen. 2007; 12: 193-195.

[324] Sasan TA, Goodarzi MT, Jamshid K, Panah MH.

Antidiabetic effects of the aqueous extract of Urtica dioica on high-fructose fed rats.

Clin Biochem. 2011; 44: S332.

http://dx.doi.org/10.1016/j.clinbiochem.2011.08.821

[325] Nickavar B, Yousefian N.

Evaluation of alpha-amylase inhibitory activities of selected antidiabetic medicinal plants.

J Verbr Lebensm. 2011; 6: 191-195.

http://dx.doi.org/10.1007/s00003-010-0627-6

[326] Bnouham M, Merhfour FZ, Ziyyat A, Mekhfi H, Aziz M, Legssyer A.

Antihyperglycemic activity of the aqueous extract of Urtica dioica.

Fitoterapia. 2003; 74: 677-681.

http://dx.doi.org/10.1016/S0367-326X(03)00182-5

[327] Farzami B, Ahmadvand D, Vardasbi S, Majin FJ, Khaghani S.

Induction of insulin secretion by a component of Urtica dioica leave extract in perifused Islets of Langerhans and its in vivo effects in normal and streptozotocin diabetic rats.

J Ethnopharmacol. 2003; 89: 47-53.

http://dx.doi.org/10.1016/S0378-8741(03)00220-4

[328] Onal S, Timur S, Okutucu B, Zihniogku F.

Inhibition of alpha-glucosidase by aqueous extracts of some potent antidiabetic medicinal herbs. Prep Biochem Biotechnol. 2005; 35: 29-36.

http://dx.doi.org/10.1081/PB-200041438

[329] Golalipour MJ, Khori V.

The protective activity of Urtica dioica leaves on blood glucose concentration and beta-cells in streptozotocin-diabetic rats.

Pak J Biol Sci. 2007; 10: 1200-1204.

http://dx.doi.org/10.3923/pjbs.2007.1200.1204

[330] Golalipour MJ, Ghafari S, Kouri V, Kestkar AA.

Proliferation of the beta-cells of pancreas in diabetic rats treated with Urtica dioica.

Int J Morphol. 2010; 28: 399-404.

[331] Domola MS, Vu V, Robson-Doucette CA, Sweeney G, Wheeler MB.

Insulin mimetics in Urtica dioica: Structural and computational analyses of Urtica dioica extracts.

Phytotherapy Res. 2010; 24: S175-S182.

http://dx.doi.org/10.1002/ptr.3062

[332] Bnouham M, Merhfour FZ, Ziyyat A, Aziz M, Legssyer A, Mekhfi H.

Antidiabetic effect of some medicinal plants of Oriental Morocco in neonatal non-insulin-dependent diabetes mellitus rats.

Hum Exp Toxicol. 2010; 29: 865-871.

http://dx.doi.org/10.1177/0960327110362704

[333] Rau O, Wurglics M, Dingermann T, Abdel-Tawab M, Schubert-Zsilavecz M.

Screening of herbal extracts for activation of the human peroxisome proliferator-activated receptor.

Pharmazie. 2006; 61: 952-956.

http://www.ncbi.nlm.nih.gov/pubmed/17152989

[334] Golalipour MJ, Ghafari S, Afshar M.

Protective role of Urtica dioica L. (Urticaceae) extract on hepatocytes morphometric changes in STZ diabetic Wistar rats.

Turk J Gastroenter. 2010; 21: 262-269.

http://www.ncbi.nlm.nih.gov/pubmed/20931430 
[335] Fazeli SA, Gharravi AM, Ghafari S, Jahanshahi M, Golalipour MJ.

Effects of Urtica dioica extract on CA3 hippocampal pyramidal cell loss in young diabetic rats.

Neur Regen Res. 2010; 5: 901-905.

[336] Gulcin I, Kufrevioglu OI, Oktay M, Buyukokuroglu ME.

Antioxidant, antimicrobial, antiulcer and analgesic activities of nettle (Urtica dioica L.).

J Ethnopharmacol. 2004; 90: 205-215.

http://dx.doi.org/10.1016/j.jep.2003.09.028

[337] Turker AU, Usta C.

Biological screening of some Turkish medicinal plant extracts for antimicrobial and toxicity activities.

Nat Prod Res. 2008; 22: 136-146.

http://dx.doi.org/10.1080/14786410701591663

[338] Toldy A, Atalay M, Stadler K, Sasvari M, Jakus J, Jung KJ, Chung HY, Nyakas C, Radak Z.

The beneficial effects of nettle supplementation and exercise on brain lesion and memory in Rat.

J Nutr Biochem. 2009; 20: 974-981.

http://dx.doi.org/10.1016/j.jnutbio.2008.09.001

[339] Modaresi M, Golchoobian H.

Effect of hydro-alcoholic extract of nettle on immune system in mice.

Asian J Chem.2012; 24: 2339-2341.

[340] Testai L, Chericoni S, Calderone V, Nencioni G, Nieri P, Morelli I, Martinotti E.

Cardiovascular effects of Urtica dioica L. (Urticaceae) roots extracts: in vitro and in vivo

pharmacological studies.

J Ethnopharmacol. 2002; 81: 105-109.

http://dx.doi.org/10.1016/S0378-8741(02)00055-7

[341] Safarinejad MR.

Urtica dioica for treatment of benign prostatic hyperplasia: a prospective, randomized, double-blind, placebo-controlled, crossover study.

J Herb Pharmacother. 2005; 5: 1-11.

http://dx.doi.org/10.1080/J157v05n04_01

[342] El Haouari M, Bnouham M, Bendahou M, Aziz M, Ziyyat A, Legssyer A, Mekhfi H. Inhibition of rat platelet aggregation by Urtica dioica leaves extracts.

Phytotherapy Res. 2006; 20: 568-572.

[343] Kanter M, Coskun O, Budancamanak M.

Hepatoprotective effects of Nigella sativa $L$ and Urtica dioica $L$ on lipid peroxidation, antioxidant enzyme systems and liver enzymes in carbon tetrachloride-treated rats.

World J Gastroenterol. 2005; 11: 6684-6688.

http://www.ncbi.nlm.nih.gov/pubmed/16425366

[344] Kandis H, Karapolat S, Yildirim U, Saritas A, Gezer S, Memisogullari R.

Effects of Urtica dioica on hepatic ischemia-reperfusion injury in rats.

Clinics. 2010; 65: 1357-1361.

http://dx.doi.org/10.1590/S1807-59322010001200021

[345] Denzler KL, Waters R, Jacobs BL, Rochon Y, Langland JO.

Regulation of inflammatory gene expression in PBMCs by immunostimulatory botanicals.

PLoS One. 2010; 5: e12561.

http://dx.doi.org/10.1371/journal.pone.0012561

[346] Gansser D, Spiteller GGG.

Aromatase inhibitors from Urtica diodica roots.

Planta Med. 1995; 61: 138-140.

http://dx.doi.org/10.1055/s-2006-958033

[347] Sharaf M, el-Ansari MA, Matlin SA, Saleh NA.

Four flavonoid glycosides from Peganum harmala.

Phytochemistry. 1997; 44: 533-536.

http://dx.doi.org/10.1016/S0031-9422(96)00531-6 
[348] Sobhani AM, Ebrahimi SA, Mahmoudian M.

An in vitro evaluation of human DNA topoisomerase I inhibition by Peganum harmala L. seeds extract and its beta-carboline alkaloids.

J Pharm Pharm Sci. 2002; 5: 19-23.

http://www.ncbi.nlm.nih.gov/pubmed/12042115

[349] Hussain Z, Waheed A, Qureshi RA, Burdi DK, Verspohl EJ, Khan N, Hasan M.

The effect of medicinal plants of Islamabad and Murree region of Pakistan on insulin secretion from INS-1 cells.

Phytother Res. 2004; 18: 73-77.

http://dx.doi.org/10.1002/ptr.1372

[350] Shapira Z, Terkel J, Egozi Y, Nyska A, Friedman J.

Abortifacient potential for the epigeal parts of Peganum harmala.

J Ethnopharmacol. 1989; 27: 319-325.

http://dx.doi.org/10.1016/0378-8741(89)90006-8

[351] Singh AB, Khaliq T, Chaturvedi JP, Narender T, Srivastava AK.

Anti-diabetic and anti-oxidative effects of 4-hydroxypipecolic acid in C57BL/KsJ-db/db mice.

Human Exp Toxicol. 2012; 31: 57-65.

http://dx.doi.org/10.1177/0960327111407227

[352] Astulla A, Zaima K, Matsuno Y, Hirasawa Y, Ekasari W, Widyawaruyanti A, Zaini NC, Morita H. Alkaloids from the seeds of Peganum harmala showing antiplasmodial and vasorelaxant activities. J Nat Med. 2008; 62: 470-472. http://dx.doi.org/10.1007/s11418-008-0259-7

[353] Misra P, Khaliq T, Dixit A, SenGupta S, Samant M, Kumari S, Kumar A, Kushawaha PK, Majumder HK, Saxena AK, Narender T, Dube A.

Antileishmanial activity mediated by apoptosis and structure-based target study of peganine hydrochloride dihydrate: an approach for rational drug design.

J Antimicrob Chemother. 2008; 62: 998-1002.

http://dx.doi.org/10.1093/jac/dkn319

[354] Rahimi-Moghaddam P, Ebrahimi SA, Ourmazdi H, Selseleh M, Karjalian M, Haj-Hassani G, Alimohammadian MH, Mahmoudian M, Shafiei M.

In vitro and in vivo activities of Peganum harmala extract against Leishmania major.

J Res Med Sci. 2011; 16: 1032-1039.

http://www.ncbi.nlm.nih.gov/pubmed/22279479

[355] Farouk L, Laroubi A, Aboufatima R, Benharref A, Chait A.

Evaluation of the analgesic effect of alkaloid extract of Peganum harmala L.: Possible mechanisms involved.

J Ethnopharmacol. 2008; 115: 449-454.

http://dx.doi.org/10.1016/j.jep.2007.10.014

[356] Bremner P, Rivera D, Calzado MA, Obon C, Inocencio C, Beckwith C, Fiebich BL, Munoz E, Heinrich M.

Assessing medicinal plants from South-Eastern Spain for potential anti-inflammatory effects targeting nuclear factor-Kappa B and other pro-inflammatory mediators.

J Ethnopharmacol. 2009; 124: 295-305.

http://dx.doi.org/10.1016/j.jep.2009.04.035

[357] Im JH, Jin YR, Lee JJ, Yu JY, Han XH, Im SH, Hong JT, Yoo HS, Pyo MY, Yun YP.

Antiplatelet activity of beta-carboline alkaloids from Perganum harmala: a possible mechanism

through inhibiting PLCgamma2 phosphorylation.

Vascul Pharmacol. 2009; 50: 147-152.

http://dx.doi.org/10.1016/j.vph.2008.11.008

[358] Bahmani M, Rafieian-Kopaei M, Parsaei P, Mohsenzadegan A.

The anti-leech effect of Peganum harmala L. extract and some anti-parasite drugs on Limnatis nilotica. Afr J Micro Res. 2012; 6: 2586-2090. 
[359] Abbasipour H, Mahmoudvand M, Rastegar F, Basij M.

Insecticidal activity of Peganum harmala seed extract against the diamondback moth, Plutella xylostella.

Bull Insect.2010; 63: 259-263.

[360] Zeng Y, Zhang Y, Weng Q, Hu M, Zhong G.

Cytotoxic and insecticidal activities of derivatives of harmine, a natural insecticidal component isolated from Peganum harmala.

Molecules. 2010; 15: 7775-7791.

http://dx.doi.org/10.3390/molecules15117775

[361] Nenaah G.

Antibacterial and antifungal activities of (beta)-carboline alkaloids of Peganum harmala (L) seeds and their combination effects.

Fitoterapia. 2010; 81: 779-782.

http://dx.doi.org/10.1016/j.fitote.2010.04.004

[362] Diba K, Shoar MG, Shabatkhori M, Khorshivand Z.

Antifungal activity of alcoholic extract of Peganum harmala seeds.

J Med Plant Res. 2011; 5: 5550-5554.

[363] Darabpour E, Bavi AP, Motamedi H, Nejad SMS.

Antibacterial activity of different parts of Peganum harmala L. growing in Iran against multi-drug resistant bacteria.

Exp Clin Sci. 2011; 10: 252-263.

[364] Sarpeleh A, Sharifi K, Sonbolkar A.

Evidence of antifungal activity of wild rue (Peganum harmala L.) on phytopathogenic fungi.

J Plant Dis Protect. 2009; 116: 208-213.

[365] Hashem M.

Antifungal Properties of Crude Extracts of Five Egyptian Medicinal Plants Against Dermatophytes and Emerging Fungi.

Mycopathologia. 2011; 172: 37-46.

http://dx.doi.org/10.1007/s11046-010-9390-6

[366] Hayet E, Maha M, Mata M, Mighri Z, Laurent G, Mahjoub A.

Biological activities of Peganum harmala leaves.

Afr J Biotec. 2010; 9: 8199-8205.

[367] Adhami HR, Farsam H, Krenn L.

Screening of medicinal plants from Iranian traditional Mmdicine for acetylcholinesterase inhibition.

Phytotherapy Res. 2011; 25: 1148-1152.

http://dx.doi.org/10.1002/ptr.3409

[368] Zheng XY, Zhang L, Cheng XM, Zhang ZJ, Wang CH, Wang ZT.

Identification of Acetylcholinesterase Inhibitors from Seeds of Plants of Genus Peganum by ThinLayer Chromatography-Bioautography.

J Planar Chromatogr Modern TLC. 2011; 24: 470-474.

http://dx.doi.org/10.1556/JPC.24.2011.6.3

[369] Herraiz T, Gonxalez D, Ancin-Azpilicueta C, Aran VJ, Guillen H.

Beta-Carboline alkaloids in Peganum harmala and inhibition of human monoamine oxidase (MAO).

Food Chem Toxicol. 2010; 48: 839-845.

http://dx.doi.org/10.1016/j.fct.2009.12.019

[370] El Gendy MAM, Soshilov AA, Denison MS, El-Kad AOS.

Harmaline and harmalol inhibit the carcinogen-activating enzyme CYP1A1 via transcriptional and posttranslational mechanisms.

Food Chem Toxicol. 2012; 50: 353-362.

http://dx.doi.org/10.1016/j.fct.2011.10.052 
[371] Lamchouri F, Settaf A, Cherrah Y, Hassar M, Zemzami M, Atif N, Nadori EB, Zaid A, Lyoussi B. In vitro cell-toxicity of Peganum harmala alkaloids on cancerous cell-lines.

Fitoterapia. 2000; 71: 50-54.

http://dx.doi.org/10.1016/S0367-326X(99)00117-3

[372] Hamsa TP, Kuttan G.

Harmine inhibits tumour specific neo-vessel formation by regulating VEGF, MMP, TIMP and proinflammatory mediators both in vivo and in vitro.

Eur J Pharmacol. 2010; 649: 64-73.

http://dx.doi.org/10.1016/j.ejphar.2010.09.010

[373] Sodaeizadeh H, Rafieiolhossaini M, Van Damme P.

Herbicidal activity of a medicinal plant, Peganum harmala L., and decomposition dynamics of its phytotoxins in the soil.

Ind Crop Prod. 2010; 31: 385-394.

http://dx.doi.org/10.1016/j.indcrop.2009.12.006 